\title{
What's in a Name?-A Short History of Coordination Chemistry from Then to Now
}

\author{
Edwin C. Constable
}

Department of Chemistry, University of Basel, BPR 1096, Mattenstrasse 24a, CH-4058 Basel, Switzerland; Edwin.constable@unibas.ch; Tel.: +41-61-207-1001

Received: 5 August 2019; Accepted: 14 August 2019; Published: 22 August 2019

\begin{abstract}
This article traces the development of coordination chemistry and shows how progress in the science has been paralleled by the development of a vocabulary and nomenclature to describe new concepts, structural features and compound types.
\end{abstract}

Keywords: coordination chemistry; history of science; nomenclature; IUPAC

\section{Introduction}

In early cultures, knowledge of the "true" name of an object or a person gave power [1,2]. The identity of the name with a true understanding of an object is nowhere more important than in the natural sciences. Coordination chemistry is concerned with compounds formed by the interaction of ligands with metal centres and its history is the story of chemistry in microcosm. In general scientific discussion, it is necessary to establish both the identity and the structure of chemical entities-"is my pink cobalt complex the same as your pink cobalt complex? What is it anyway?" The development of coordination chemistry has been characterized by a search for identity and understanding. Understanding the development of the systematics of nomenclature allows us to understand the development of chemistry itself. This article looks at the development of the nomenclature of coordination compounds from the earliest times to the modern dominance of the International Union of Pure and Applied Chemistry (IUPAC) as the arbiter for, and regulator of, nomenclature for the chemistry community. I will trace the need-driven evolution of nomenclature from a desire to establish a unique identity for an individual compound, through nomenclature that indicates composition and relationships to other known compounds, to systems that describe both composition and three-dimensional structure. As the information content of the nomenclature increases, I also note that the ease of correct human interpretation of that information often decreases. In the future, the search for chemical information will increasingly be computer based and there is a need to develop both new algorithms and artificial intelligence methods for defining, storing and retrieving structural data. The descriptors for unique chemical identification are unlikely to resemble modern nomenclature systems. This highlights a divergence in the philosophy of chemical nomenclature and the recognition that machines and people will need different grammars.

The spelling, capitalization and abbreviations used in text extracts and citations correspond to those in the original. The only exception is that the long $\mathrm{s}\left(\int\right)$ found in early manuscripts is transcribed into the modern round $\mathrm{s}$ form [3]. Where printed names in the literature differ from contemporary usage, the literature form is used; for example, in the references from the German literature, S.M. Jörgensen is used instead of S.M. Jørgensen. The author is responsible for all errors and loss of nuance in any translations. In the course of the last 250 years, many journals have changed their titles and sequence of volume numbering; where possible, the journal abbreviation corresponds to the Chemical Abstracts Service Source Index (CASSI) recommendation for the appropriate year of publication [4]. The reader should also note that many of the early journal titles have been subsumed into modern 
journals and the originals are not always simple to identify and locate-caveat emptor. Finally, where formulae are given for compounds, they generally correspond to the modern formulation; the literature in the 19th century CE is particularly confusing because of unclear and inconsistent usage of equivalent (proportional) and atomic weights, stemming back to Dalton's assumption of the formulae HO and $\mathrm{NH}$ for water and ammonia, respectively, together with the belief that oxidation must involve the addition of oxygen atoms (the electron was only discovered in 1897). Occasionally, the contemporary formulae will be presented for interest.

\section{Early History of Coordination Chemistry}

Coordination chemistry as a discipline is relatively new, first emerging in an identifiable form in the 19th century CE. This section traces the scientific development of coordination chemistry up to that time.

\subsection{From Prehistory to History}

The prehistory of coordination chemistry is very simple-there is virtually none [5,6]! Although coordination compounds have a long and honourable history of application, they were not recognized or systematically studied until the modern era. Coordination chemistry, like metallurgy, is a discipline in which technological and æsthetic application predated scientific investigation. Colour has been fundamental to the cultural and historical development of modern society and is a characteristic of coordination chemistry [7].

Probably one the first applications of coordination chemistry was the use of mordants to fix dyes to fibres [8] and there is evidence for the dying of cloth from 7000 BCE. The earliest dyes came from natural sources, such as plants, lichen, insects or fungi. These were extracted with water and transferred to the cloth by immersion of the fabric in the dye solution $[9,10]$. Some dyes alone gave good and permanent colours which did not wash off, but others only bound when additional substances, called mordants (French mordre, to bite), were present. Many of the commonest mordants are simple metal salts, in particular those of aluminium, copper, iron, chromium and tin. An early dye obtained from the root of the madder plant, Rubia tinctorum, contains alizarin (Figure 1) [11]. The general features responsible for binding the dye to a fibre involve metal ions coordinating to oxygen atoms of the alizarin and of the cloth-as a result, the dye is not removed from the fabric in a normal washing cycle. The red dyes entered popular culture and the description of British soldiers of the 18th and 19th centuries CE as "redcoats" refers to the use of Turkey Red (alizarin with an aluminium mordant) to dye their jackets. Trivial names such as Turkey Red identify the colouring material but give no clue as to their chemical constitution.

It is almost inconceivable that the alchemists and iatrochemists did not encounter coordination compounds, but there is little or no surviving documentary evidence. As "ammoniakal liquors" were prevalent in the alchemical oeuvre, which in turn was obsessed with the transformation of metals (in particular base metals to gold), it is certain that the characteristic colours of ammine complexes must have been observed. The earliest empirical description is due to the work of Andreas Libavius at the end of the 16th century CE who described a blue colour in the reaction of brass (an alloy of copper and zinc) with aqueous ammonia (aqua calcis, in qua sal ammonius solutus sit, eodem [caeruleo] colore tingitur super orichalco; si aquam calcis cum sale ammonio ponas per noctem in pelui orichalcea, caerulea euadit; lime water, in which sal ammoniac is dissolved, gives vivid [blue] colours with copper; if thick brass armour is left overnight in a basin containing lime water and sal ammoniac, a blue colour emerges) [12]. 

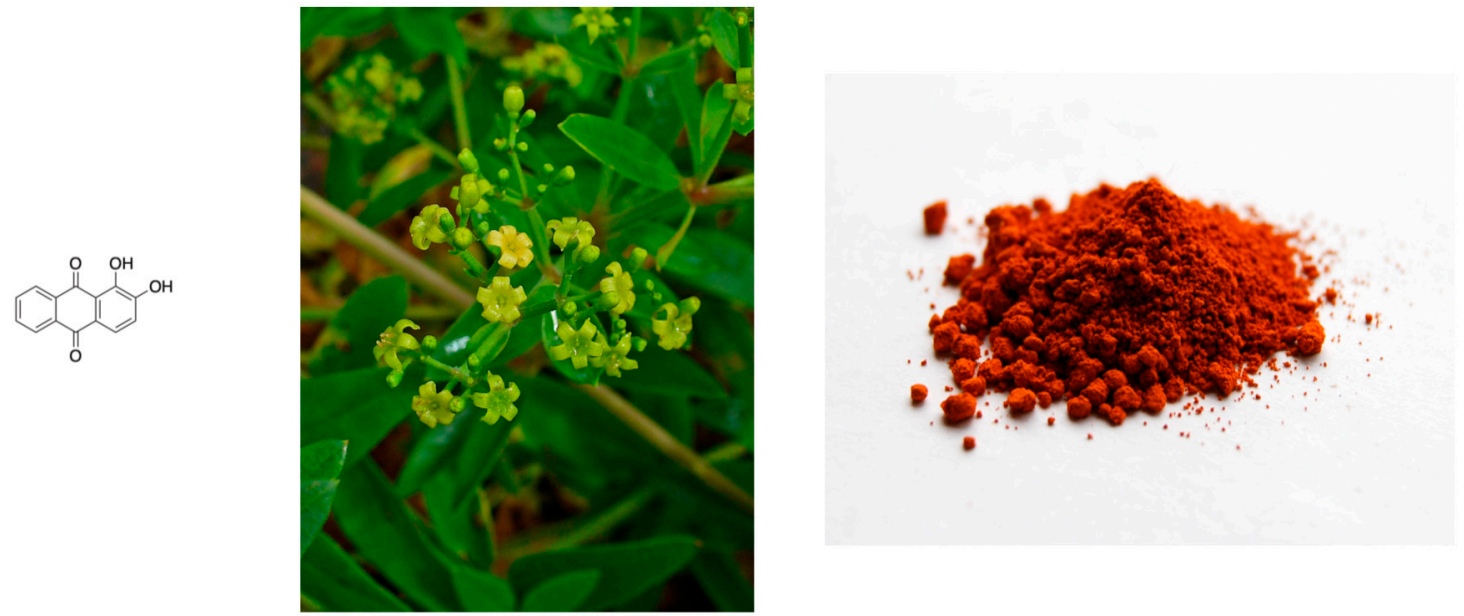

(a)

(b)

(c)

Figure 1. (a) The structure of alizarin; (b) the plant from which it is extracted, Rubia tinctorum (https://commons.wikimedia.org/wiki/File:Rubia_tinctorum_002.JPG); (c) alizarin the dye (https://en.w ikipedia.org/wiki/Alizarin\#/media/File:Alizarin-sample.jpg). The alizarin binds to hydroxy groups of the fabric by coordination to metal ions such as $\mathrm{Al}^{3+}$ or $\mathrm{Cr}^{3+}$.

\subsection{Location, Location, Location}

By the early Middle Ages, a body of chemical knowledge was developing in the European and Arabian spheres of influence, and individual chemical compounds began to be identified. In contrast to today, early chemistry is characterized less by awareness of individual researchers and their communication, but more by an awareness of the evolving and accumulated body of wisdom that entered the communal knowledge. Where chemical compounds were individually identified, the names were more often associated with their geographical origin than their chemical properties. Examples include elements such as copper (named after Cyprus) or compounds such as Tyrian purple (after Tyre, an ancient Phoenician port), Egyptian blue (an artificial lapis lazuli prepared in the Middle East from malachite), or Paris Green $\left(\mathrm{Cu}\left(\mathrm{CH}_{3} \mathrm{CO}_{2}\right)_{2} \cdot 3 \mathrm{Cu}\left(\mathrm{AsO}_{2}\right)_{2}\right)$.

Coordination chemistry enters this arena around 1704 when Diesbach accidentally prepared a new blue pigment (Figure 2a) which became known as Prussian blue (Preussisch blau) or Berlin blue (Berlinisch blau) [14-16]. The new blue pigment was rapidly commercialized and made available for purchase, with the first painting using it, The Entombment of Christ by Pieter van der Werff, dated 1709. Diesbach never revealed his method of preparation and the first reliable description dates from $1724[17,18]$. Following the publication of the recipe, the same pigment was prepared in France and subsequently sold as Paris blue [19-21]. Prussian blue and Turnbull's blue were originally formulated as iron(III) hexacyanidoferrate(II) and iron(II) hexacyanidoferrate(III), respectively, but subsequently shown to be the same [22,23]. The crystal structure of $\mathrm{Fe}_{4}\left[\mathrm{Fe}(\mathrm{CN})_{6}\right]_{3} \cdot x \mathrm{H}_{2} \mathrm{O}$ was only determined in 1977 and an idealized representation is given in Figure 2b. Prussian blue continues to be an important pigment with some 12 million kilograms being prepared annually, primarily for use in inks, and has had societal impact, ranging from the characteristic blue colour of the uniforms of the Prussian infantry of the 18th and 19th centuries CE, through engineers' "blueprints" to the trivial name of "prussic acid" for hydrocyanic acid, much loved as a poison by detective writers. One of the very earliest fictional descriptions of the use of cyanide as a poison comes from the author and poet Letitia Elizabeth Landon, in her book Ethel Churchill, or, the two brides [24] from 1837 CE. This work is of note as it is set in 1725 $\mathrm{CE}$ and describes the fictional preparation of hydrocyanic acid some 50 years before its real-world 
isolation by Scheele [25]. It is sad to mention that Letitia Elizabeth Landon herself died in 1838 by deliberately or accidentally drinking prussic acid [26]. Even the name cyanide links us back to the blue colour of the compound from which it was prepared (ancient Greek, kv́ $\alpha v \varsigma$, kyanos, blue). Heating Prussian blue generated an orange-brown pigment called Prussian brown, which indicates a chemical relationship between the two compounds, but gives little further information.

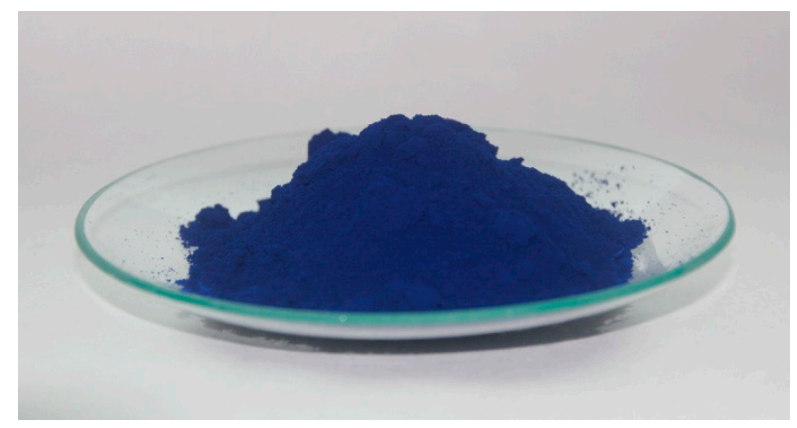

(a)

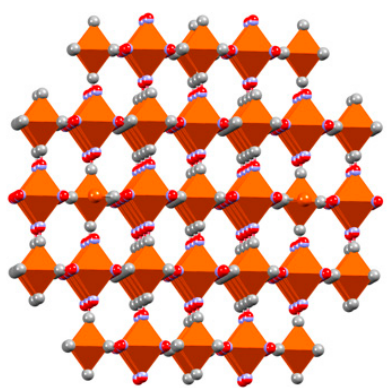

(b)

Figure 2. (a) The pigment Prussian blue was first prepared by Diesbach in 1704 (https://en.wikipedia.o rg/wiki/Prussian_blue_(medical_use)\#/media/File:Pigment_Berliner_Blau.JPG); (b) the idealized crystal structure of the pigment, $\mathrm{Fe}_{4}\left[\mathrm{Fe}(\mathrm{CN})_{6}\right]_{3} \cdot x \mathrm{H}_{2} \mathrm{O}$ which was only determined some 270 years later [13]. The structure is disordered with some $\left[\mathrm{Fe}(\mathrm{CN})_{6}\right]$ octahedra being randomly absent [13].

In conclusion, historical names for the identification of coordination compounds with the place of discovery or preparation served a useful role, but was neither consistent nor sustainable and gave no information regarding constitution and little concerning the relationships among compounds. Individual compounds frequently had multiple and unrelated names.

\subsection{A Neglected Study of Platinum Chemistry}

Most accounts of the development of coordination chemistry now move directly to the beginning of the 19th century CE. Nevertheless, the last half of the 18th century CE sees a remarkable, and often neglected, publication showing how the modern scientific method was becoming accepted and also providing one of the earliest detailed descriptions of the behaviour of coordination compounds in solution. In Commercium Philisophico-technium; or, The Philosophical Commerce of Arts: designed as An Attempt to Improve Arts, Trades, and Manufactures, William Lewis describes inter alia studies on gold and platinum (Figure 3) [27]. He reports the yellow colour of the $\left[\mathrm{AuCl}_{4}\right]^{-}$ion after dissolution of gold in aqua regia and also the isolation of solid $\mathrm{Na}\left[\mathrm{AuCl}_{4}\right]$ and $\mathrm{H}\left[\mathrm{AuCl}_{4}\right]$. The description of the chemistry of platinum is especially complete and precise and includes the dissolution of the metal in aqua regia, the isolation of solid hexachloridoplatinate(IV) species and some red or yellow materials from reaction with ammonium chloride likely to be the $\left[\mathrm{Pt}\left(\mathrm{NH}_{3}\right)_{2} \mathrm{Cl}_{2}\right]$ isomers.

Although the experimental scientific aspects were well developed in this remarkable work, there is little if any knowledge of the constitution of the materials or attempt to uniquely identify them with names containing chemical information. 


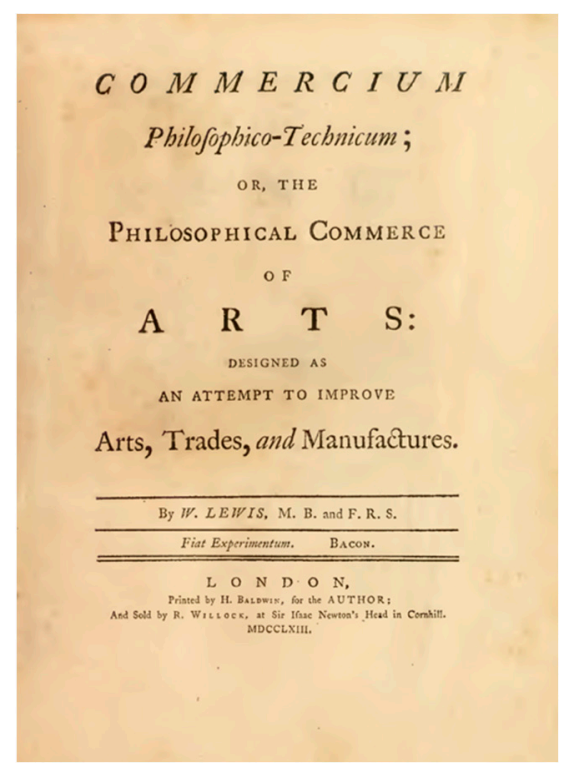

Figure 3. The title page of a neglected work describing detailed chemical (and alchemical) studies on gold and platinum, in the Commercium Philisophico-technium; or, The Philosophical Commerce of Arts; designed as An Attempt to Improve Arts, Trades, and Manufactures, William Lewis describes inter alia studies on gold and platinum [27].

\section{The Modern Era}

\subsection{A New Millennium and New Visions-The Start of the 19th Century of the Common Era}

To summarize the story to date, at the beginning of the 19th century CE, inorganic materials were generally identified by names (or symbols) with origins lost in antiquity. Coordination compounds were a rare and exotic breed with names often associated with their geographical origin. An example of the lack of system is seen in "The list of simples, \&c", given by Buchan in 1790 [28]. Here, under "Mercury", we find entries for: crude, calcinated, Aethiops mineral, calomel, corrosive sublimate, red precipitate and white precipitate. In modern terms, these refer to mercury metal, $\mathrm{HgO}, \mathrm{HgS}, \mathrm{Hg}_{2} \mathrm{Cl}_{2}, \mathrm{HgCl}_{2}, \mathrm{HgO}$ and $\left[\mathrm{Hg}\left(\mathrm{NH}_{3}\right)_{2} \mathrm{Cl}_{2}\right]$ (or $\left.\left[\mathrm{Hg}\left(\mathrm{NH}_{2}\right) \mathrm{Cl}\right]\right)$, respectively. Even in Buchan, we find two names for mercury(II) oxide, which was also known variously as red oxide of mercury, red pulvis solaris, pulvis serpentum, mercurius praecipitatus, hydrargyri nitrico-oxidum, hydrargyri oxidum rubrum, deutoxide of mercury, binoxide of mercury, peroxide of mercury or calx of mercury, amongst others. Collections of information about medicinal compounds and preparations were known as pharmacopoeia, and in the course of the 18th century $\mathrm{CE}$ the nomenclature of compounds for medicinal use in pharmacopoeia became a contentious issue. Although the modern-thinking doctors and apothecaries recognized the needs for consistency and unambiguity in identifying substances to be used in medicine, the conservatism inherent in the profession resulted in a tendency to retain the old-fashioned and obscure nomenclature of the alchemical era. To address this, the Royal College of Physicians in London published in 1742 proposals for a reform of their pharmacopoeia [29], although these were critically received, with Wilcock commenting, "How comes it then to pass, that a work so necessary to the public health, should be so ill executed? that a work well becoming the dignity of physicians to prosecute with the utmost attention, and finish with the greatest care, should fall so far short of any degree of perfection, as to be so full of mistakes and inaccuracies, that the most ignorant cannot omit seeing them" [30]. The full reform of the pharmacopoeia did not occur until the beginning of the 19th century CE [31,32].

\subsection{Some First Approaches to Systematics}

In the course of the 18th century $\mathrm{CE}$, it became increasingly clear that scientific progress in chemistry was being hindered by the lack of a clear and universally accepted method of nomenclature 
to uniquely identify compounds. Not only did compounds have irrational or historical names, but frequently individual species had multiple names. For example, names for potassium carbonate, $\mathrm{K}_{2} \mathrm{CO}_{3}$, included cineres clauellati, salt of tartar, alkali of wine lees, cendres gravellées and fixed nitre [33]. Another example of the difficulty is found in the naming of iron(II) tartrate, which in the solid state was called extract of Mars, but in solution as tartarised tincture of Mars [33].

However, the need for, and benefit of, identifying compounds on the basis of chemical constitution was not universally accepted. Henry Cavendish, the discoverer of dihydrogen, was not convinced that properties were independent of the mode of preparation, and believed that forms of $\mathrm{Hg}_{2} \mathrm{Cl}_{2}$, known as mercuris dulcis sublimatus and mercurius dulcis praecipitatus according to its synthesis, had different properties. He stated in 1787 that he thought it was "very wrong to attempt to give them names expressive of their composition" [34]. Although his perspicacity predated modern concepts such as allotropism and polymorphism, it did not particularly assist the movement for nomenclature reform. Nevertheless, the disquiet with the status quo was becoming general, and chemists in France and Germany took the lead both in criticising and in proposing more logical systems. Today, we primarily remember the contributions of de Lavoisier (in the text I will use the aristocratic form of his name other than when citing the contemporary literature), but his system did not spring fully formed into the world, and it would be particularly disingenuous to neglect the pioneering work of Pierre Joseph Macquer [35-37] and Antoine Baume [38].

Macquer was very critical of the contemporary chemical nomenclature and although in his 1766 Dictionnaire de Chymie [37] he took the opportunity to make some recommendations for preferred and better names, he did not really introduce a new system. Nevertheless, he clearly understood the process of salt formation and proposed a nomenclature in which the parent acid was identifiable in the name of a salt. One of the earliest more systematic approaches came from Louis Bernard Guyton de Morveau (post-French revolution known as de Guyton), who was inspired by the work of Tobgren Bergman, who had begun to introduce more rational names $[39,40]$. Bergman corresponded with the great Swedish naturalist Carl Linnaeus, who introduced the familiar hierarchical nomenclature for living organisms and de Morveau had a vision of applying a Linnaean binomial nomenclature to inorganic compounds, and in Sur les Dénominations Chymiques, la nécessité d'en perfectionner le Systéme, $\mathcal{E}$ les régles pour y parvenir [41] formulated five clear principles for the derivation of names:

Principle 1. That every substance should be denominated by a name, and not by a phrase;

Principle 2. That the names should be given according to the nature of the things intended to be signified by them;

Principle 3. That when the character of the substance is not sufficiently well known to determine the denomination, a name which has no meaning should be preferred to one which might give an erroneous idea;

Principle 4. In the choice of new denominations, those which have their root in the most generally known dead languages should be preferred, in order that the word may be suggested by the sense, and the sense by the word;

Principle 5. The denominations should be arranged with care, to suit the genius of the language for which they are proposed.

The examples that he presented correspond closely to the modern binary nomenclature of salts: nitre alumineux (aluminium nitrate), muriate calcaire (calcium chloride), arseniate de potasse (potassium arsenate). One wonders how well the naming of element 118, oganesson, fulfils principles four and five [42]!

The next crucial development was the publication of Méthode de nomenclature chimique by Louis Bernard Guyton de Morveau, Antoine-Laurent de Lavoisier, Claude Louis Berthollet, and Antoine François Fourcroy in 1787 (Figure 4) [43,44]. This remarkable document transformed chemistry and established the binary notation for salts with which we are familiar today. Although concerned 
nominally with nomenclature, the document can also be seen as the manifesto of the anti-phloginosist movement and proposed a nomenclature based upon oxygène and not phlogiston [45,46]. The Méthode identified simple substances, acids, metals, earths and alkalis. These could be combined to make compound names. The basic grammar adopted persists in modern nomenclature. For example, two series of acids containing nitrogen were identified (acide nitrique and acide nitreux; $\mathrm{HNO}_{3}$ and $\mathrm{HNO}_{2}$, respectively) with the ending -ique denoting the maximum number of bonded oxygen atoms and -eux less oxygen. These replaced the earlier names for $\mathrm{HNO}_{3}$ (acide nitreux blanc, acide nitreux dégazé, acide nitreux déphlogistiqué) and $\mathrm{HNO}_{2}$ (acide nitreux phlogistiqué). These two acids gave rise to salts called nitrates and nitrites, which were then incorporated into the names of salts by combining with the appropriate base or metal as in $\mathrm{Ca}\left(\mathrm{NO}_{3}\right)_{2}$, Nitrate de calcaire, $\mathrm{AgNO}_{3}$, Nitrate d'argent; $\mathrm{Pb}\left(\mathrm{NO}_{3}\right)_{2}$, Nitrate de plomb.

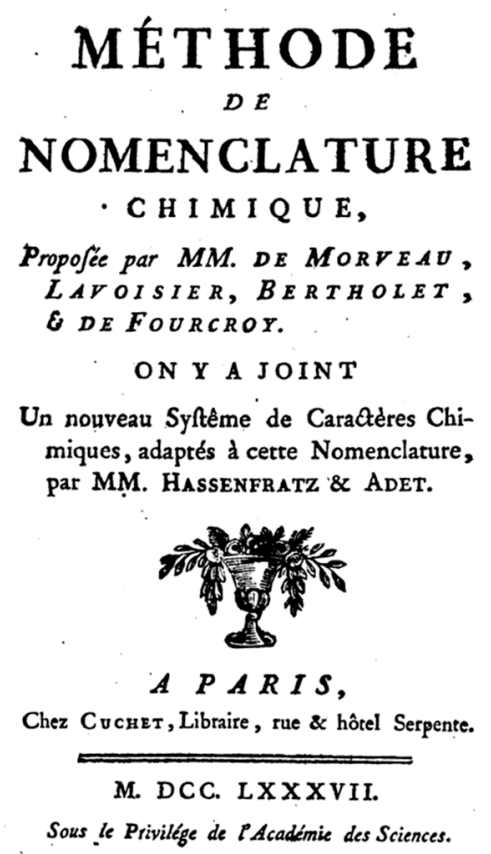

Figure 4. The title page of Méthode de nomenclature chimique by Louis Bernard Guyton de Morveau, Antoine-Laurent de Lavoisier, Claude Louis Berthollet, and Antoine François Fourcroy in 1787.

The authors of the Méthode anticipated that their proposals might be controversial "On conçoit que nous n'avons pu remplir ces différens objets, sans blesser souvent les usages reçus, E sans adopter des dénominations qui paroîtront dures $\mathcal{E}$ barbares dans le premier moment; mais nous avons observé que l'oreille s'accouturnoit promptement aux mots nouveaux; sur-tout lorsqu'ils se trouvent liés à un systême général $\mathcal{E}$ raisonné" (We understand that we have not been able to fill these different objectives, without often hurting the received uses, \& without adopting denominations that will appear harsh \& barbaric at first glance; but we have observed that the ear quickly gets used to new words; especially when they are linked to a general \& reasoned system) - and they were not to be disappointed in their apprehensions! Jean Claude de la Métherie (and post-revolution also known as Delamétherie or de Lamétherie) was very influential in France in his role as the editor of the journal Observations sur la Physique and became the mouthpiece of the resistance to the new proposals "Elle emploie des mots durs, barbares, qui choquent l'oreille, E ne sont nullement dans la génie de la langue Françoise, tels que carbonate, nitrate, sulfate \&c."; It uses hard, barbaric words that shock the ear, \& are by no means in the spirit of the French language, such as carbonate, nitrate, sulphate \&c.). For example, specifically concerning nitrogen compounds, de la Métherie wrote, "Les nitrates, les nitrites sont des mots nouveaux durs; ainsi je conserverai le mot nitre" (Nitrates, nitrites are new hard words; so I will keep the word nitre) [47]. He follows with some 55 points in which he does not accept, criticizes, modifies or rejects the new 
nomenclature system. The Méthode was first translated into English in 1788 and the anglophone community responded similarly to the francophone; the proposals were generally rejected by the phlogistonists and accepted by the anti-phlogistonist community [44]. The preface of Keir's The First Part of a Dictionary of Chemistry [48] is a diatribe against the anti-phlogistonists in general, and the authors of the Méthode and Pierre Joseph Macquer in particular, “... their own system is only a mere exposition of facts, they perceive no impropriety in giving the permanence of language to their ideas by the words oxygene, hydrogene, \&c. Accordingly, their nomenclature is intirely (sic) relative to their peculiar theory". Similar conservative views were expressed in Dickson's An essay on chemical nomenclature from 1796 [49]. Nevertheless, the new nomenclature was slowly, but universally, accepted and today we never question the binary structure of compound names. One of the key developments was the adoption and further elaboration of the proposed system by Berzelius [50].

Although these developments provide the background to the nomenclature that was to develop, the heroes of our story, the coordination compounds played no role in the early years and the scheme proposed in the Méthode de Nomenclature Chimique could not be used directly for such compounds. Nevertheless, changes were also occurring in the world of coordination chemistry.

\subsection{On the Cusp-Citizen Tassaert and the Beginnings of Cobalt Complex Chemistry}

The next scientific description of the solution behaviour of a coordination compound came from Tassaert in a 1798 publication (Figure 5) [51]. He gives the first description of a cobalt(III) ammine complex and the first experimental observation that a metal ion in a coordination compound behaves differently to the same metal ion in "simple" aqueous solution; "Another rather surprising phenomenon is that, when cobalt nitrate is precipitated by excess ammonia, a precipitate is formed which is immediately re-dissolved to give a brown solution; but if this solution is immediately treated with a lot of water, a green precipitate is formed consisting only of pure cobalt oxide, which dissolves in acids, and gives solutions of a beautiful pink color; if we leave the cobalt solution in ammonia exposed to air for a long period, we can dilute it with as much water as we wish, without it forming a precipitate." In the egalitarian and revolutionary environment of France in 1798, the author is only identified as Citizen Tassaert, although Partington [52] quite reasonably equates him with the B.M. Tassaert, who translated Klaproth's six volume work, Beiträge zu chemischen Kenntniss der Mineralkörper, into French [53]. However, Tassaert made no further speculation as to the nature of the compounds he had obtained and proposed neither composition nor structure. Nevertheless, these studies opened the door to the investigation of solutions of metal compounds. Needless to say, in the absence of knowledge of constitution, a meaningful nomenclature was precluded.

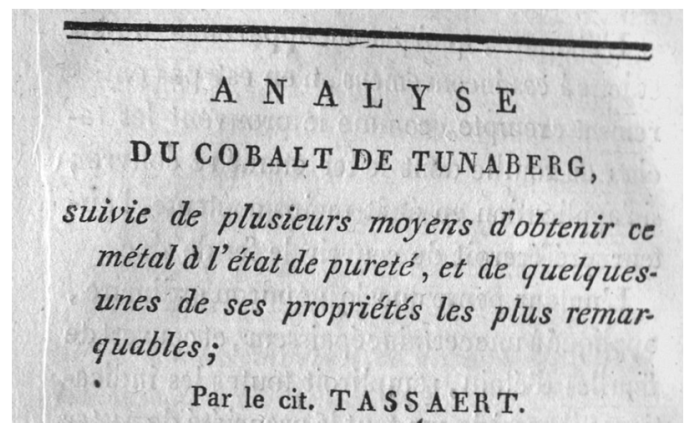

Figure 5. The title of Tassaert's 1798 publication which describes the formation of brown solutions when ammoniacal solutions of cobalt(II) salts are exposed to the air for long periods of time [51].

A number of other early studies on cobalt coordination chemistry deserve to be mentioned at this point. Leopold Gmelin [54] and Emil Dingler [55] reported the formation of cobalt(III) ammine complexes (neutrales kobaltsaures Ammoniak) from the reactions of cobalt compounds with ammonia and air in 1822 and 1829, respectively. Although Karl Georg Winkelblech disagreed with the interpretation 
of these results [56], subsequent studies by Beetz [57] and Rammelsberg [58,59] confirmed the formation of these ammonia complexes of cobalt.

\subsection{The Cult of Personality}

Coordination chemistry now entered a rich phase of expansion in which large numbers of new compounds were discovered. As analytical methods and instruments were developed, in particular the introduction of the analytical balance, attributed to Joseph Black around 1750 [60], the constitution of the materials, subject to the formulaic consequences of the contemporary or selected equivalent weight could be determined. However, although new models for, and an understanding of, valence were developing, especially for organic compounds, these did not help in understanding the nature of the coordination compounds. Similarly, the concepts of three-dimensional structure and isomerization were only generally accepted at the extreme end of the 19th century CE.

Against this background, a new trend emerged-that of naming the compound after its discoverer. This nomenclature model had both advantages and disadvantages. The names Fischer's salt (1848, Salpetrichtsaures Kobaltoxydkali, $\mathrm{K}_{3}\left[\mathrm{Co}\left(\mathrm{NO}_{2}\right)_{6}\right]$ ) [61] or Erdmann's salt (1866, Salpetrigsaures Diamin-Kobaltoxyd mit salpetrigsaurem Kali, $\left.\mathrm{NH}_{4}\left[\mathrm{Co}\left(\mathrm{NH}_{3}\right)_{2}\left(\mathrm{NO}_{2}\right)_{4}\right]\right)$ [62] unambiguously describe the materials obtained from the reaction of aqueous solutions of cobalt salts with $\mathrm{KNO}_{2}$ in the absence and presence of ammonia, respectively. Erdmann's salt could also possess a cis- or trans-arrangement of the ammine ligands in the $\left[\mathrm{Co}\left(\mathrm{NH}_{3}\right)_{2}\left(\mathrm{NO}_{2}\right)_{4}\right]^{3-}$ anion, although these possibilities were not recognized at the time. It took another 90 years before the trans- structure was crystallographically established [63]. As the names were not linked to the constitution, their usage depended upon other researchers being aware of the name given to a particular compound. If the compound was prepared by a new route or if the initial work was not known to a new researcher, the given name might not be used or a new name assigned. Nevertheless, with a limited number of active researchers, the system worked reasonably well, and a few of these names are still used. Compounds named after their discoverers include Vauquelin's salt (1813, [Pd( $\left.\left.\left.\mathrm{NH}_{3}\right)_{4}\right]\left[\mathrm{PdCl}_{4}\right]\right)$ [64], Cleve's salt (1871, [ $\left.\mathrm{Pt}\left(\mathrm{NH}_{3}\right)_{3} \mathrm{Cl}_{2}\left[\mathrm{PtCl}_{4}\right]\right)$ [65], Peyrone's salt (1844, cis-[Pt $\left.\left.\left(\mathrm{NH}_{3}\right)_{2} \mathrm{Cl}_{2}\right]\right)$ [66], Zeise's salt (sal kalico-platinicus inflammabilis, $\mathrm{K}\left[\mathrm{Pt}\left(\mathrm{C}_{2} \mathrm{H}_{4}\right) \mathrm{Cl}_{3}\right]$ ) [67-69], Gmelin's salt $\left(\mathrm{K}_{3}\left[\mathrm{Fe}(\mathrm{CN})_{6}\right]\right)[70]$, and Reinecke's salt $\left(1863\right.$, [ $\left.\left.\mathrm{NH}_{4}\right]\left[\mathrm{Cr}(\mathrm{NCS})_{4}\left(\mathrm{NH}_{3}\right)_{2}\right] \cdot \mathrm{H}_{2} \mathrm{O}\right)$ [71]. Salts containing the $\left[\mathrm{Cr}(\mathrm{NCS})_{4}\left(\mathrm{NH}_{3}\right)_{2}\right]^{-}$anion were known as reineckates, a non-recommended and unsystematic usage that persists to this day [72]. Although the names above convey no meaningful chemical information, the system was often modified to include some chemical or physical information about the compounds. Information about the anion could be included in the names, for example, Gros' nitrate (trans- $\left.\left[\mathrm{PtCl}_{2}\left(\mathrm{NH}_{3}\right)_{4}\right]\left(\mathrm{NO}_{3}\right)_{2}\right)$ [73], Gerhardt's nitrate (trans- $\left.\left[\mathrm{Pt}(\mathrm{OH})\left(\mathrm{NH}_{3}\right)_{4}\left(\mathrm{NO}_{3}\right)\right]\left(\mathrm{NO}_{3}\right)_{2}\right)$ [74], Hadow's chloride $\left(\left[\mathrm{PtCl}(\mathrm{OH})\left(\mathrm{NH}_{3}\right)_{4}\right] \mathrm{Cl}_{2}\right)$ [75] or Vortmann's fusco sulfate (mixture of $\left[\left(\mathrm{NH}_{3}\right)_{4} \mathrm{Co}(\mu-\mathrm{O})(\mu-\right.$ $\left.\mathrm{NH}) \mathrm{Co}\left(\mathrm{NH}_{3}\right)_{4}\right]\left(\mathrm{SO}_{4}\right)$ and $\left[\left(\mathrm{NH}_{3}\right)_{4} \mathrm{Co}\left(\mu-\mathrm{OSO}_{3} \mathrm{H}\right)(\mu-\mathrm{NH}) \mathrm{Co}\left(\mathrm{NH}_{3}\right)_{4}\right]_{2}\left(\mathrm{SO}_{4}\right)_{3}$ [76]. Additional meaningful information such as colour or partial chemical constitution could also be included, as in Chugaev's red salt $\left(\left[\mathrm{Pt}\left(\mathrm{C}(\mathrm{NHMe})_{2} \mathrm{~N}_{2} \mathrm{H}_{2}\right](\mathrm{CNMe})_{2}\right] \mathrm{Cl}_{2}\right)$ [77], Magnus' green salt $\left(\left[\mathrm{Pt}\left(\mathrm{NH}_{3}\right)_{4}\right]\left[\mathrm{PtCl}_{4}\right]\right)$ [78], Magnus' pink salt ([Pt $\left.\left.\left(\mathrm{NH}_{3}\right)_{4}\right]\left[\mathrm{PtCl}_{4}\right]\right)$ [79], Buckton's double salt $\left(\mathrm{K}_{2}\left[\mathrm{Pt}(\mathrm{SCN})_{6}\right]\right)$ [80], Thomson's double salt [81], Cleve's triamine $\left(\left[\mathrm{Pt}\left(\mathrm{NH}_{3}\right)_{3} \mathrm{Cl}\right] \mathrm{Cl}\right)$ [82] or Zeise's dimer $\left(\left[\left(\mathrm{C}_{2} \mathrm{H}_{4}\right) \mathrm{CIPt}(\mu-\mathrm{Cl})_{2} \mathrm{Pt}\left(\mathrm{C}_{2} \mathrm{H}_{4}\right) \mathrm{Cl}\right]\right)[67,69]$. Already the deficits of the system are apparent: Magnus' pink and green salts appear to have the same constitution and there is no apparent relationship between these salts and their palladium analogue, Vauquelin's salt. Worse was to come. Today, a synthetic chemist may prepare many hundreds or thousands of new materials in the course of her or his career and it was not so different in the 19th century CE. Accordingly, the literature began to describe compounds such as Reiset's first ([Pt $\left.\left.\left(\mathrm{NH}_{3}\right)_{4}\right] \mathrm{Cl}_{2}\right)$ [83] and second (trans-[Pt $\left.\left.\left(\mathrm{NH}_{3}\right)_{2} \mathrm{Cl}_{2}\right]\right)$ chlorides [84], Reiset's first $\left(\right.$ cis- $\left.\left[\mathrm{Pt}\left(\mathrm{NH}_{3}\right)_{4}\right](\mathrm{OH})_{2}\right)[84,85]$ and second bases $\left(\right.$ cis- $\left.-\left[\mathrm{Pt}\left(\mathrm{NH}_{3}\right)_{2}(\mathrm{OH})_{2}\right]\right)[84,85]$, and Cossa's first $\left(\mathrm{K}\left[\mathrm{PtCl}_{3}\left(\mathrm{NH}_{3}\right)\right] \cdot \mathrm{H}_{2} \mathrm{O}\right)[86,87]$ and second salts $\mathrm{K}\left[\mathrm{PtCl}_{5}\left(\mathrm{NH}_{3}\right)\right] \cdot \mathrm{H}_{2} \mathrm{O}[87]$.

This short list of named compounds illustrates some of the fundamental problems confronting these early chemists; Peyrone's salt and Reiset's second chloride (cis and trans-[Pt $\left.\left(\mathrm{NH}_{3}\right)_{2} \mathrm{Cl}_{2}\right]$, respectively) as well as Magnus' green and pink salts $\left(\left[\mathrm{Pt}\left(\mathrm{NH}_{3}\right)_{4}\right]\left[\mathrm{PtCl}_{4}\right]\right)$ had the same composition-Cavendish's 
caution was well justified [34]. Significant progress could not be made before the nature and structure of coordination compounds were better understood.

\subsection{When Colour Was King}

At this point, it is appropriate to introduce some studies which not only provided exquisite experimental detail and studies of cobalt(III) coordination compounds but also proposed a nomenclature based upon their constitution. This story starts in 1847 (19 years before the birth of Alfred Werner) with studies by Friedrich August Ludwig Karl Wilhelm Genth who at the time was assistant to Bunsen and chemistry lecturer at the University of Marburg [88]. These studies were only published in 1851 after his move to the United States and even then, in a relatively obscure journal [89]. In contrast to the Tassaert report of the preparation of cobalt(III) ammine species in solution, Genth follows up the work of Gmelin, Dingler, Winkelblech, Beetz and Rammelsberg and describes the isolation and characterization of a number of solid cobalt(III) ammine complexes and their transformation in solution. In particular, he isolated solid, carmine red $\left[\mathrm{Co}\left(\mathrm{NH}_{3}\right)_{5} \mathrm{Cl}\right] \mathrm{Cl}_{2}$ after neutralizing an aqueous reaction mixture of cobalt(II) chloride or sulphate with $\mathrm{NH}_{4} \mathrm{Cl}$ and excess ammonia in the presence of air with $\mathrm{HCl}$ after $4-5$ weeks. He also describes the presence of orange $\left[\mathrm{Co}\left(\mathrm{NH}_{3}\right)_{6}\right]^{3+}$ in solution. He formulated the first compound as $\mathrm{Co}_{2} \mathrm{O}_{3} \cdot 3 \mathrm{NH}_{4} \mathrm{Cl}$, the deviation from the modern formula arising from the use of equivalent weights and ultimately from Dalton's assumption of $\mathrm{HO}$ as the formula of water. The obscure nature of this publication by Genth meant that many European researchers were unaware of his work, and independent studies on the cobalt(III) ammine complexes were reported in 1851 by Claudet $[90,91]$. Claudet prepared $\left[\mathrm{Co}\left(\mathrm{NH}_{3}\right)_{5} \mathrm{Cl}\right] \mathrm{Cl}_{2}$ in the same manner as Genth and formulated it $\mathrm{Co}_{2}\left(\mathrm{NH}_{2}\right)_{2} \cdot 3 \mathrm{NH}_{4} \mathrm{Cl}$, which apart from the doubling of the cobalt, corresponds to the modern formulation. Fremy made brief reports of the same compound and other cobalt(III) complexes in 1851 [92,93] and 1852 [94] and published a full paper in 1852 [95]. This latter publication introduces the use of colour to name the compounds, and describes $\left[\mathrm{Co}\left(\mathrm{NH}_{3}\right)_{6}\right] \mathrm{Cl}_{3}$ as sels de lutéocobaltique and used sels de roséocobaltique for both $\left[\mathrm{Co}\left(\mathrm{NH}_{3}\right)_{5} \mathrm{Cl}\right]^{2+}$ and $\left[\mathrm{Co}\left(\mathrm{NH}_{3}\right)_{5}\left(\mathrm{H}_{2} \mathrm{O}\right)\right]^{3+}$. Subsequent publications followed from Genth and Gibbs [96-98] and from Gibbs alone [99-101] in which the colour-based nomenclature of Frémy was adopted, anglicised and extended. The name luteocobalt was used for $\left[\mathrm{Co}\left(\mathrm{NH}_{3}\right)_{6}\right]^{3+}$ salts, roseocobalt was reserved for $\left[\mathrm{Co}\left(\mathrm{NH}_{3}\right)_{5}\left(\mathrm{H}_{2} \mathrm{O}\right)\right]^{3+}$ derivatives and new colour-based names purpureocobalt and xanthocobalt were introduced for $\left[\mathrm{Co}\left(\mathrm{NH}_{3}\right)_{5} \mathrm{Cl}\right]^{2+}$ and $\left[\mathrm{Co}\left(\mathrm{NH}_{3}\right)_{5}\left(\mathrm{NO}_{2}\right)\right]^{2+}$ salts, respectively. Gibbs and Genth made extensive descriptions of the crystal habit of the compounds they isolated (Figure 6a). Subsequently, Jørgensen introduced the descriptions violeocobalt and praseocobalt for derivatives of cis- and trans-[Co( $\left.\left(\mathrm{NH}_{3}\right)_{4} \mathrm{Cl}_{2}\right]^{+}$, respectively.

By 1857, Gibbs and Genth had adopted the suggestion of Kolbe to use a connecting circumflex as a symbol of conjugation, giving the notation in Figure 6 for the luteo salt [98]. This representation is of interest as it implies a difference between the conjugated ammonia molecules and the ionic chlorides.

This colour-based nomenclature can be viewed as the first systematic approach to relating the constitution of a series of coordination compounds through their names. Logical extensions of the nomenclature lead to constructions such as bromopurpureokobalt for $\left[\mathrm{Co}\left(\mathrm{NH}_{3}\right)_{5} \mathrm{Br}\right]^{2+}$ [102] and nitratopurpureokobalt for $\left[\mathrm{Co}\left(\mathrm{NH}_{3}\right)_{5}\left(\mathrm{NO}_{2}\right)\right]^{2+}[103]$ and less logically, tetraminroseokobalt for $\left[\mathrm{Co}\left(\mathrm{NH}_{3}\right)_{4}\left(\mathrm{H}_{2} \mathrm{O}\right)_{2}\right]^{3+}$. The nomenclature was then extended from cobalt(III) complexes to other metals, in particular rhodium and iridium, with the names implying (in modern formulation) the presence of the following complex cations: luteo $\left[\mathrm{M}\left(\mathrm{NH}_{3}\right)_{6}\right]^{3+}$, purpureo $\left[\mathrm{M}\left(\mathrm{NH}_{3}\right)_{5} \mathrm{Cl}\right]^{2+}$, violeo cis- $\left[\mathrm{M}\left(\mathrm{NH}_{3}\right)_{4} \mathrm{Cl}_{2}\right]^{+}$, praseo trans- $\left[\mathrm{M}\left(\mathrm{NH}_{3}\right)_{4} \mathrm{Cl}_{2}\right]^{+}$, flavo cis- $\left[\mathrm{M}\left(\mathrm{NH}_{3}\right)_{4}\left(\mathrm{NO}_{2}\right)_{2}\right]^{+}$, croceo trans- $\left[\mathrm{M}\left(\mathrm{NH}_{3}\right)_{4}\left(\mathrm{NO}_{2}\right)_{2}\right]^{+}$, xantho $\left[\mathrm{M}\left(\mathrm{NH}_{3}\right)_{5}\left(\mathrm{NO}_{2}\right)\right]^{2+}$, isoxantho $\left[\mathrm{M}\left(\mathrm{NH}_{3}\right)_{5}(\mathrm{ONO})\right]^{2+}$ and roseo $\left[\mathrm{M}\left(\mathrm{NH}_{3}\right)_{5}\left(\mathrm{OH}_{2}\right)\right]^{2+}$. In this extension, the descriptions are divorced from their original relationship to colour. By 1890, Sophus Mads Jørgensen was discussing the Purpureocharakter of complexes [104] and the chemistry of Luteorhodium and Roseorhodium [105] complexes. The latter experimental work contains oxymoronic (even transcendental) statements such as "ein weisser, prachtig glanzender Niederschlag des Roseonitrats abscheidet" (a white, splendidly glossy precipitate of roseonitrate separates out) [106]. Jørgensen used this nomenclature 
up to his final publication on chromium and rhodium complexes [107] and it was generally used by coordination chemists until the proposals of Werner were broadly accepted, making alternative naming based upon both structure and constitution more relevant. Subsequent extensions of the system included a broadening of the ligand type to include chelating species such as ethane-1,2-diamine [108] and 2,2'-bipyridine [109].

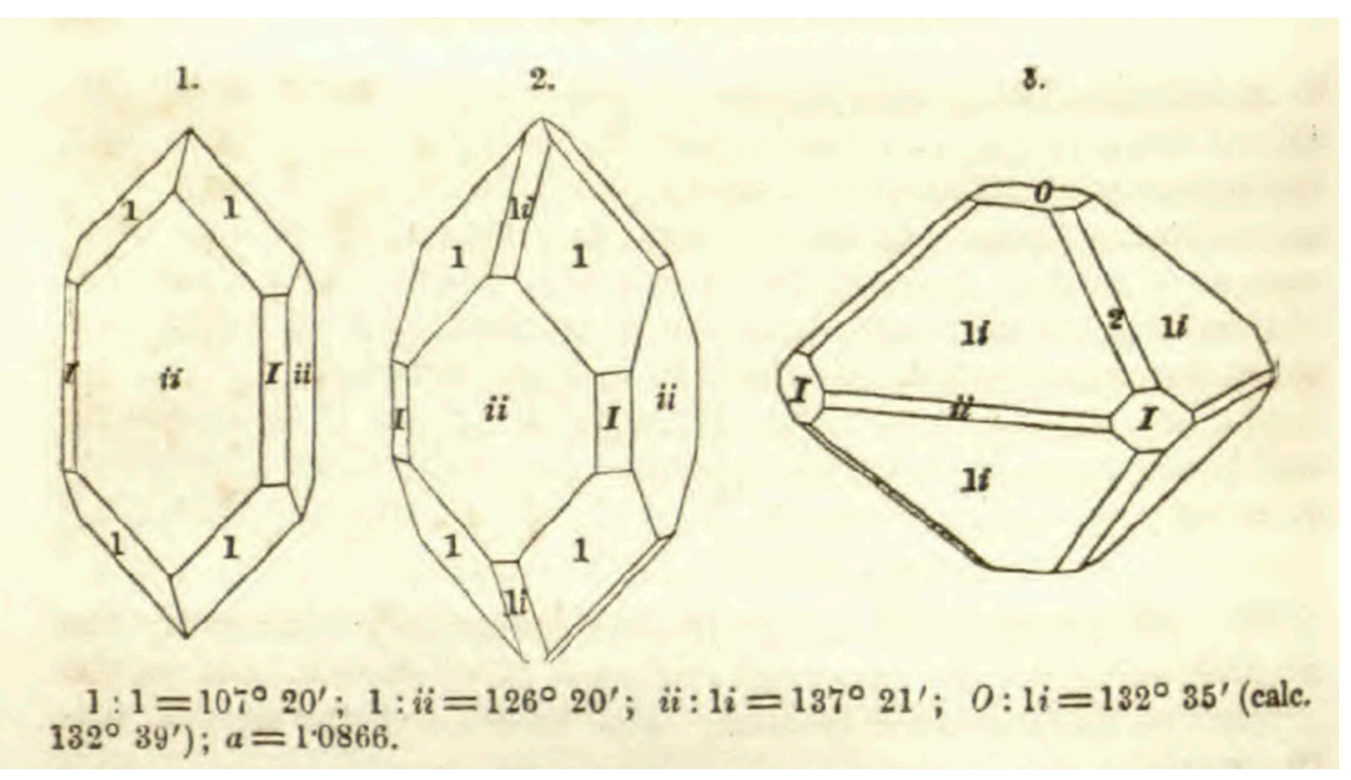

(a)

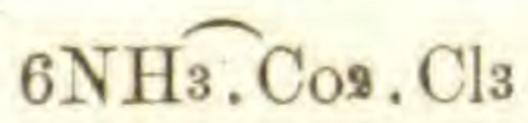

(b)

Figure 6. (a) Illustration of the crystal form of the "sulphate of roseocobalt" $\left[\mathrm{Co}\left(\mathrm{NH}_{3}\right)_{5}\left(\mathrm{H}_{2} \mathrm{O}\right)\right]_{2}\left(\mathrm{SO}_{4}\right)_{3}$ (made available under Creative Commons Attribution-NonCommercial-ShareAlike 4.0 (CC BY-NC-SA 4.0) license) [96]. (b) Representation of the luteo salt, $\left[\mathrm{Co}\left(\mathrm{NH}_{3}\right)_{6}\right] \mathrm{Cl}_{3}$, by Gibbs and Genth (made available under Creative Commons Attribution-NonCommercial-ShareAlike 4.0 (CC BY-NC-SA 4.0) license) [98]. The connecting circumflex indicates the conjugation of the ammonia molecules to the doubled cobalt atom.

Carl Weltzien published three papers attempting to rationalize the constitution of these cobalt complexes into the prevalent "ammonium theory" [110-112]. Although these papers are models of logical analysis, they clearly identify the problem of formulating these compounds in a meaningful manner before the Werner model. An example of the complexity of notation is seen in Figure 7, which presents the proposed "structure" of the sulfate salt of the luteo complex $\left[\mathrm{Co}\left(\mathrm{NH}_{3}\right)_{6}\right]^{3+}[110]$. In a strange twist of fate, Werner reanimated the ammonium model in a paper from 1903 entitled Die Ammoniumsalze als einfachste Metallammoniake (The ammonium salts as the simplest metal-ammine complexes) [113]. 
Aus den Luteokobaltsalzen bilden sie sich endlich, indem

auf 1 Mol. letzterer Salze $1 \mathrm{Mol}$. Ammoniak austritt :

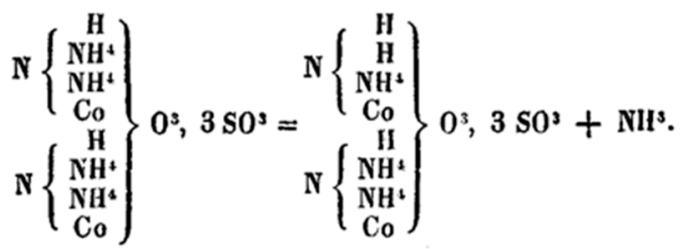

Figure 7. The Weltzien formulation of title of the sulfate salt of the luteo complex $\left[\mathrm{Co}\left(\mathrm{NH}_{3}\right)_{6}\right]^{3+}$ from 1856 (Copyright Wiley. Used with permission) [110]. There is little, if any, resemblance to the subsequent Werner formulations beyond the overall stoichiometry (corrected for the doubled cobalt atom).

To summarize, the colour-based nomenclature made an excellent relationship between constitution and the name, but in the absence of structural knowledge proved deficient. According to Chemical Abstracts SciFinder, the usage had almost died out by the latter half of the 20th century CE, with the last references to violeo- [114], luteo- [115], praseo [116] and roseo- [117] compounds appearing to be between 1951 and 1966. The most recent use of this nomenclature appears to date from 2017, when a single publication used the description purpureo to describe $\left[\mathrm{Co}\left(\mathrm{NH}_{3}\right)_{5} \mathrm{Cl}_{\mathrm{Cl}} \mathrm{Cl}_{2}[118]\right.$.

\subsection{The Problem of Proportional/Equivalent Weights}

We have referred on a number of occasions to the problems of atomic and equivalent weights. This was a genuine problem for scientists in the 19th century and presents an ongoing problem to those who read the literature from that period. It is appropriate to summarize the situation at this point in the text. A remarkably good summary is given by William Odling in his 1855 translation of the book Notation, Classification and Nomenclature by Auguste Laurent [119]. Odling identifies four different systems used by Laurent in his text. The first is the system that was commonly used in the United Kingdom in the 1850s, with formulae of $\mathrm{HCl}, \mathrm{HO}, \mathrm{NaCl}$ and $\mathrm{AgO}$ for hydrochloric acid, water, sodium chloride and silver(I) oxide, respectively. The second is the Berzelius system with the corresponding formulae $\mathrm{H}^{2} \mathrm{Cl}^{2}, \mathrm{H}^{2} \mathrm{O}, \mathrm{NaCl}^{2}$ and $\mathrm{AgO}$. The third is the so-called four-volume system from Gerhardt, which yields formulae of $\mathrm{H}^{2} \mathrm{Cl}^{2}, \mathrm{H}^{2} \mathrm{O}, \mathrm{Na}^{2} \mathrm{Cl}^{2}$ and $\mathrm{Ag}^{2} \mathrm{O}$. The final method was the two-volume system from Gerhardt which gave formulae $\mathrm{HCl}, \mathrm{H}^{2} \mathrm{O}, \mathrm{NaCl}$ and $\mathrm{Ag}^{2} \mathrm{O}$ and which Laurent selected as his favoured form and correspond to modern usage. The equivalent weights are in the ratio for $\mathrm{H}-\mathrm{Cl}-\mathrm{O}$ of 1:35.5:8 for the first system and 1:35.5:16 for the other three. Berzelius introduced a strike-through for elements using the first model, resulting in the notation $\mathrm{H}, \mathrm{Cl}$ and $\mathrm{N}$.

\section{The Troubled Transition into the Modern Era}

\subsection{Valence-A Surprisingly Complex Concept}

A concept lying at the core of the transformation of chemistry in the second half of the 19th Century CE is that of valence [120,121]. We will use the term valence rather than valency other than in quotations from the original literature; this corresponds to IUPAC usage, although as an aside, the IUPAC definition, "The maximum number of univalent atoms (originally hydrogen or chlorine atoms) that may combine with an atom of the element under consideration, or with a fragment, or for which an atom of this element can be substituted" [122], clearly assigns a valence of five to the carbon in methanium $\mathrm{CH}_{5}{ }^{+}$. It is interesting to note that IUPAC itself is not completely satisfied with this definition and has initiated a project in which the "objective is to find out whether a comprehensive definition of valence can be formulated" [123]. The rationalization and genesis of the stereoelectronic model of organic chemistry stems from the early theories of valence, types and radicals, with the earliest and most cogent proponent being August Kekule [124]. Despite the importance of valence as a concept for the development of organic chemistry and as the crucial driver for the development of the modern picture of coordination chemistry proposed by Werner, it is a remarkably diffuse concept [125]. 
As Ramsberg comments, "The success of structure theory .... relied on the principle of valence, which raised the inevitable question about what it actually was. Strictly speaking, valence ... was a number that possessed no physical significance" [120]. This is no post-modern interpretation, but a real statement of a frustration that was well-recognized by contemporary authors. In 1876, Victor Meyer wrote, "Allein diese Arbeitsfülle und die grosse Zahl der gewonnenen Vortheile haben niemals das Bewusststein unterdrücken können, dass wir über das eigentliche Grundprincip unserer heutigen Anschauungen, über die Nature dessen, was wir eine Valenz oder Verwandtschaftseinheit nennen, vorläufig noch vollkommen im Unklaren sind" (The sheer volume of work and the large number of advantages gained have never been able to suppress the awareness that we are currently completely unclear about the basic principle of our current views and the nature of what we call valence or affinity) [126]. How did this unsatisfactory state of affairs arise?

The origin of the concept of valence lies with the father of organometallic chemistry, Edward Frankland, who, in 1852, observed, "When the formulae of inorganic chemical compounds are considered, even a superficial observer is struck with the general symmetry of their construction ... it is sufficiently evident ... no matter what the character of the uniting atoms may be, the combining power of the attracting element, if I may be allowed the term, is always satisfied by the same number of these atoms" [127]. Frankland's combining power is the first modern formulation of the concept of valence. Over the next few years, "combining power" was described using the terms Sättigungskapazität (saturation capacity), Atomigkeit (atomicity), Werthigkeit (value) and finally Valenz (valence). This ultimate formulation was proposed by Carl Wichelhaus [128] (Gebraucht man "Valenz" als kürzeres Wort an Stelle des von A. W. Hofmann eingeführten "Quantivalenz" in demselben Sinne, so ist es zunächst klar, dafs zur Bestim mung der relativen Gröfse dieser ",atomfesselnden Kraft” nur diejenigen Verbindungen dienen können, welche ein Molecul repräsentiren: If one uses "valence" as a shorter word in place of the "quantivalence" introduced by A.W. Hofmann in the same sense, it is initially clear that only those compounds which represent a molecule can serve to determine the relative magnitude of this "atomic bounding force". This contraction of Hofmann's Quantivalenz [129] was generally accepted after its adoption by Kekulé [124].

In the next section, we will see that as a concept, valence served organic chemistry well, but performed a disservice to the inorganic discipline. In his original publication from 1852, Frankland identified that a given element could have multiple valences [127], specifically discussing a group of 15 elements in terms of those with a combining power (valence) of three, such as $\mathrm{NH}_{3}, \mathrm{PH}_{3}$ and $\mathrm{PCl}_{3}$ and a combining power of five, such as $\mathrm{NH}_{4} \mathrm{I}$ and $\mathrm{PH}_{4} \mathrm{I}$. It is unfortunate that he did not directly compare $\mathrm{PCl}_{3}$ and $\mathrm{PCl}_{5}$, both of which had been prepared very early in the 19th century CE [130,131]. By 1858, Kekulé was proposing a fixed valence for elements; although he was aware of the prior work of Frankland, he did not equate the combining power (and by inference the variable combining power) with valence [132]. Kekulé was remarkably successful in rationalizing the structures of organic compounds in terms of a fixed valence of four for carbon, and extended the fixed valence idea to elements such as nitrogen and oxygen with fixed valences of three and two, respectively. The fixed valence of four for carbon necessitated multiple bonds (or free valences). In his early work, Kekulé seems to ignore the problem of carbon monoxide-if carbon and oxygen have valences of four and two, respectively, this compound should not exist.

Inorganic compounds presented Kekulé some challenges and he introduced the concept of molecular compounds to address the problem of variable valence: "A côté de ces combinaisons atomiques nous devons distinguer une seconde catégorie de combinaisons, que je désignerai par le nom combinaisons moléculaires" (In addition to these atomic combinations we must distinguish a second category of combinations, which I will refer to as molecular combinations) [133]. Taking $\mathrm{PCl}_{5}$ as an example, Kekule formulated this as $\mathrm{PCl}^{3}, \mathrm{Cl}^{2}$ which rapidly evolved into the modern type of formulation $\mathrm{PCl}_{3} \cdot \mathrm{Cl}_{2}$ and is the origin of the dot notation that is still encountered, especially in the non-chemical literature, for ammines and hydrates such as $\mathrm{CrCl}_{3} \cdot 6 \mathrm{NH}_{3}$ or $\mathrm{CrCl}_{3} \cdot 6 \mathrm{H}_{2} \mathrm{O}$.

In modern notation, it is clear that the term valence was used with variable meanings in the latter half of the 19th Century CE, sometimes in the sense of the oxidation state and sometimes in the sense 
of the number of bonded atoms, and the concept of variable valence was not universally accepted. The frustration of the chemical community is well expressed by Madan in 1869, "It is very much to be regretted that the subject of chemical nomenclature is in such an unsettled state. It seems a real reproach to chemists that scarcely two text-books can be found in which the same system of names is adopted, and that there is hardly a single number of a scientific periodical which does not contain specimens of totally different systems" [134]. This latter document is worth reading, if only to discover the merits and demerits of replacing the name sulfuric acid with brimstonic acid.

A remarkable overview of the state of chemical understanding and nomenclature at the beginning of the last half of the 19th century CE is provided by Williamson [135], in which the -ic and -ous endings for higher and lower oxidation states of transition metal compounds is clearly enunciated ( $\mathrm{SnO}$, stannous oxide; $\mathrm{Fe}_{2} \mathrm{O}_{3}$, ferric oxide), names which were still in use when I began my chemical education! This document also formulates some of the issues confronting contemporary chemists in the 1860s: the names nitric and nitrous acid denoted $\mathrm{N}_{2} \mathrm{O}_{5}$ and $\mathrm{N}_{2} \mathrm{O}_{3}$, respectively, which generated $\mathrm{HNO}_{3}$ and $\mathrm{HNO}_{2}$ (hydric nitrate and hydric nitrite) by the addition of water (or hydric oxide). This latter usage predates by some 150 years the recommendation of the use of the term hydron by IUPAC [136,137]. A final example concerning a transition metal compound from Williamson shows the danger of using nomenclature formalism reductio ad absurdum, "A neutral oxide, like the body $\mathrm{MnO}_{2}$, now called peroxide of manganese, ought perhaps, in anticipation of its being some day related to salt-like derivatives, to be called permanganic acid." In modern usage $\mathrm{MnO}_{2}$ is not a peroxide (dioxide(2-)) and the term permanganic acid would generally be taken to mean $\mathrm{HMnO}_{4}\left(\right.$ not $\left.\mathrm{H}_{2} \mathrm{MnO}_{3}\right)$.

\subsection{Variable Valence and the Werner-Jorgensen Controversy}

The debate between Werner and Jørgensen is well-documented and will not be rehearsed in detail here [138-141]. Nevertheless, it is so important to our modern understanding of the structure and bonding in coordination compounds, that the origins and highlights will be presented. Our interest lies in how the ultimately successful views of Werner prevailed and defined the approach to nomenclature of coordination compounds that persists to this day. It is informative to look at the origins of the Jørgensen model to understand how the concepts of valence, which were so successful in providing a rationalization of organic chemistry, proved to be a hurdle to the understanding of coordination chemistry. The Jørgensen model encompassed the empirical nomenclature described in Section 3.5 above, but this was not extended to a more systematic structure-based approach.

The debate should not be dismissed in terms of a successful versus an unsuccessful model, as the Werner model was based upon the painstaking and accurate experimental work of Jørgensen and others, and the refinement of Werner's ultimately accepted model was on the basis of its sequential modification in light of the detailed criticisms from Jørgensen. Although early accounts portray Jørgensen gracefully conceding defeat to his rival [139-141], revisionist analysis suggests that he was a recidivist who never really abandoned his own theory [138].

It all began in 1839, when Charles Gerhardt introduced into organic chemistry the term copule to describe radicals (in the contemporary not the modern sense) which could be linked in pairs [142]. He used this originally for describing salts of organic acids, but the usage was extended by Jakob Berzelius to cover a more general linkage in a pairwise manner or into chains of copulated compounds (Paarlinge oder gepaarte Verbindungen) [143].

This model worked exceptionally well in organic chemistry where chains of carbon atoms allowed the rationalization of many structures and structural types. However, the extension of the general proposals of Berzelius to the rest of the periodic table was criticized heavily at the time [144]. Berzelius extended the copulation model to metal complexes in his annual reviews of progress in science, for example, denoting $\left[\mathrm{Ni}\left(\mathrm{NH}_{3}\right)_{6}\right] \mathrm{Cl}_{2}$ as $\mathrm{NiCl}+3 \mathrm{NH}^{3}$ in which the strike-through, in this case, denotes that the ammonia is copulated in a chain [145].

In his monograph Die chemie derjetztzeit vom standpunkte der electrochemischen auffassung. Aus Berzellius lehre entwickelt, Blomstrand developed and clarified the Berzelius model and introduced 
a new notation for the copulated ammonia molecules and also shows how other complexes such as $\mathrm{K}_{4}\left[\mathrm{Fe}(\mathrm{CN})_{6}\right]$ can be represented (Figure 8) [146]. These representations have a number of interesting points. Firstly, the chlorides are associated at the end of the copulated ammonia ligands in $\left[\mathrm{Co}\left(\mathrm{NH}_{3}\right)_{6}\right] \mathrm{Cl}_{2}$ and the representation implies a valence of two for the cobalt and two equivalent chains each containing three ammonia molecules and one chloride. Similarly, in $\mathrm{K}_{4}\left[\mathrm{Fe}(\mathrm{CN})_{6}\right]$ the iron has a valence of two and each chain of three copulated cyanides has two potassium ions associated. Figure 9 shows the representations of the cobalt(III) complexes that we have discussed in the previous sections and illustrates a number of interesting features of the chain theory. The raised Roman numerals are not modern oxidation numbers, but rather an indication of the valence (in this case in the sense of the coordination number). If we take $\left[\mathrm{Co}\left(\mathrm{NH}_{3}\right)_{5} \mathrm{Cl}\right] \mathrm{Cl}_{2}$ (purpureo) as an example, the double atom notation $\mathrm{Co}$ gives a modern formulation of $\mathrm{Co}_{2}\left(\mathrm{NH}_{3}\right)_{10} \mathrm{Cl}_{6}$ which possesses the correct stoichiometry. The double atoms were considered to be able to bind 6 other atoms, giving a valency for the doubled cobalt of six, meaning that two chlorines are directly attached and two types of copulated chains, one with two ammonia and one with three, are present, each terminating in a chloride. The luteo compound also contains a double atom, but has the correct modern stoichiometry, but now three types of copulated chains, with one, two and three ammonia molecules, respectively. It is unclear how Blomstrand arrived at the particular chain lengths for his copulated ammonia molecules.

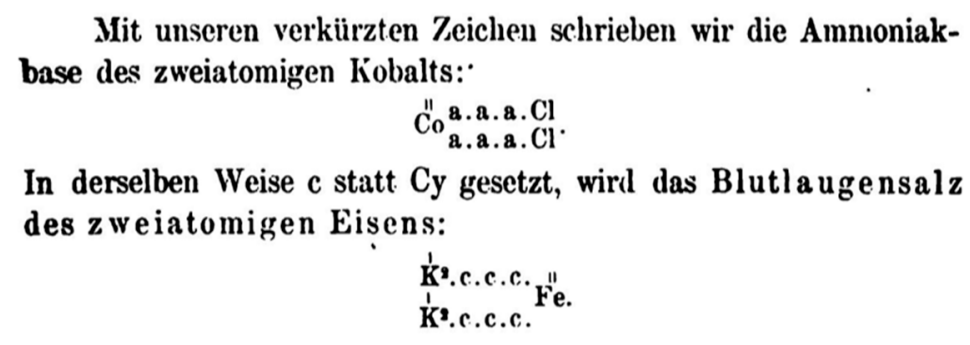

Figure 8. The Blomstrand representation of the Berzelius copulated formulae for metal complexes taken from Die chemie derjetztzeit vom standpunkte der electrochemischen auffassung. Aus Berzellius lehre entwickelt [146]. The abbreviation a is for ammonia and $\mathrm{c}$ is for $\mathrm{CN}$.

Jørgensen originally formulated the luteo compounds in the same way as Blomstrand, with doubled atoms and three different chain lengths for the copulated ammonia molecules (Figure 10a) [147]. However, by 1890 he had made two important changes. Firstly, the doubled atoms were replaced by a single cobalt and, secondly, the distribution of the ammonia in the conjugated chains was changed to favour those with four ammonia molecules [148]. We note, in passing, that this formulation implies five different types of ammonia molecule and two different types of chlorine in $\left[\mathrm{Co}\left(\mathrm{NH}_{3}\right)_{6}\right] \mathrm{Cl}_{3}$. The identification of the conjugated chain of four ammonia molecules was on the basis of systematic observations of complexes in which ammonia ligands had been replaced by ethane-1,2-diamine and became a common structural feature of the Jørgensen model.

The origin of the modern description of coordination compounds as complexes also lies in this period. Werner used the term in his first publication on coordination compounds: "Am den eben besprochenen Verbindungen, also denjenigen, in jenen gleichsain ein Komplex $M A_{6}$, enthalten ist, wobei $A$ sowohl Ammoniak als auch Wasser oder ein anderes Molekül sein kann ..." (On the compounds discussed above, i.e., those in which a complex $\mathrm{MA}_{6}$ is present, where $\mathrm{A}$ can be ammonia as well as water or another molecule ....) [149]. Jørgensen only seems to have adopted the description Komplex from 1894 onwards $[150,151]$. 


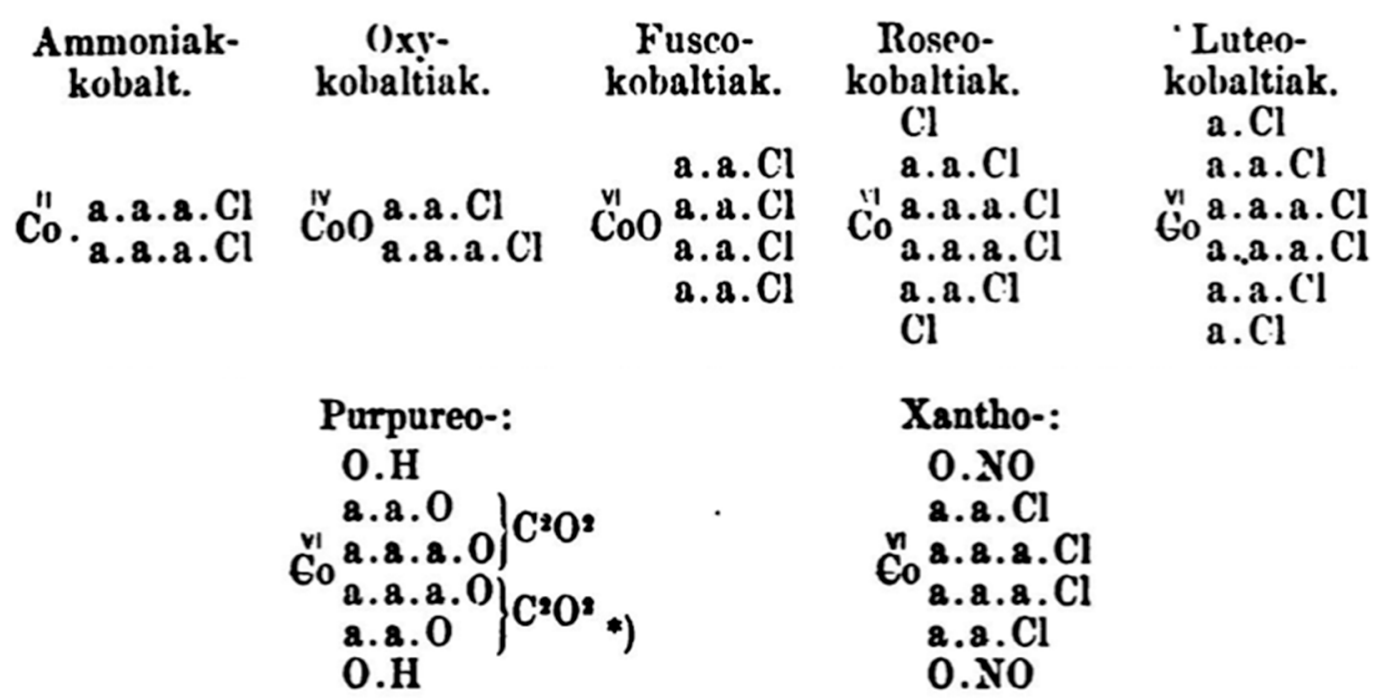

(a)

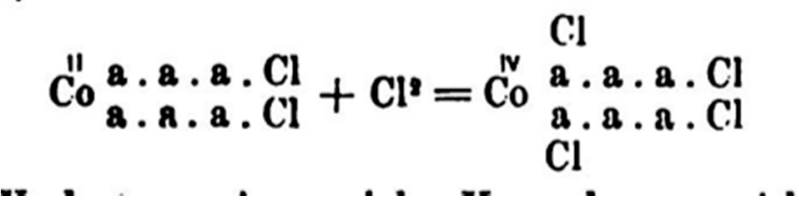

(b)

Figure 9. (a) The Blomstrand representations of classical cobalt(III) ammine complexes and (b) a reaction scheme representing the oxidation of $\left[\mathrm{Co}\left(\mathrm{NH}_{3}\right)_{6}\right] \mathrm{Cl}_{2}$ to $\left[\mathrm{Co}\left(\mathrm{NH}_{3}\right)_{6}\right] \mathrm{Cl}_{3}[146]$.

$$
R_{2}\left\{\begin{array}{l}
\mathrm{H}_{3} \mathrm{~N} \cdot \mathrm{X} \\
\mathrm{H}_{3} \mathrm{~N} \cdot \mathrm{H}_{3} \mathrm{~N} \cdot \mathrm{X} \\
\mathrm{H}_{3} \mathrm{~N} \cdot \mathrm{H}_{3} \mathrm{~N} \cdot \mathrm{H}_{3} \mathrm{~N} \cdot \mathrm{X} \\
\mathrm{H}_{3} \mathrm{~N} \cdot \mathrm{H}_{3} \mathrm{~N} \cdot \mathrm{H}_{3} \mathrm{~N} \cdot \mathrm{X} \\
\mathrm{H}_{3} \mathrm{~N} \cdot \mathrm{H}_{3} \mathrm{~N} \cdot \mathrm{X} \\
\mathrm{H}_{3} \mathrm{~N} \cdot \mathrm{X} \\
\quad \text { Luteosalze }
\end{array}\right.
$$

(a)

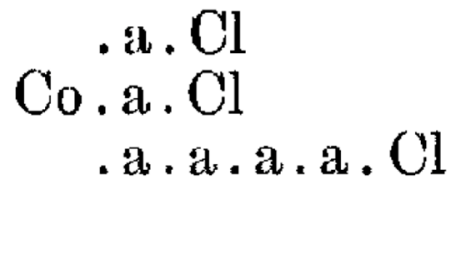

(b)

Figure 10. (a) Jørgensen's early description of the luteo salts $\left(\mathrm{R}_{2}=\right.$ doubled cobalt, chromium or rhodium) with different lengths of copulated ammonia molecules (Copyright Wiley. Used with permission) [147]; (b) The revised formulation from 1890 with a single cobalt atom and a preferred chain length of four ammonia molecules $\left(\mathrm{a}=\mathrm{NH}_{3}\right)$ (Copyright Wiley. Used with permission) [148].

The Blomstrand-Jørgensen model was based on a vast body of experimental work and precise observations. The proposals were internally self-consistent and accounted for the experimental facts reasonably well. With the benefit of hindsight, there are three aspects that the model did not successfully address. The first is that the nature of the interactions between the ammonia or other molecules or atoms in the conjugated chain were unknown and undefined. This limited application of the model to new systems as it was not clear what molecules would come into questions as ligands. The second equally fundamental problem relates to the meaning of valence and the confusion between what we today call the oxidation state and the coordination number. Finally, the chain model did not address the spatial arrangement of the ligands about the metal. Although it would have been possible to 
introduce a "modern" type of nomenclature for the structures generated by the chain model, this does not appear to have been done.

\subsection{Werner-Not Just One, But Now Primary and Secondary Valence}

In 1893, Alfred Werner proposed a new model for coordination compounds in his publication "Beitrag zur Konstution anorganische Verbindungen" (Contribution to the constitution of inorganic compounds) in which all of the key elements of modern coordination chemistry are to be found [149]. Although his training and early studies were in the field of organic chemistry, he brought his knowledge of the emerging understanding of molecular structure and valence to inorganic chemistry. His earliest work with Arthut Hantzsch concerned the stereochemistry of nitrogen compounds [152-154] and his ability to think about the three-dimensional arrangement of atoms in space was critical to his subsequent contributions to inorganic chemistry. His understanding of the three-dimensional structures of organic species is summarized in an early publication from 1891 [155].

The transition from the stereochemistry of nitrogen to coordination compounds with ammonia bound to metal centres was perhaps a natural one. Although he was a talented and prolific experimentalist, he initially approached this by surveying the literature of coordination compounds, dominated in the latter quarter of the 19th century CE by the work of Jørgensen. He analysed the problems associated with the lack of clarity regarding valence and the need to have absurdly high and variable valencies according to the Blomstrand-Jørgensen model. His genius was to identify two types of valence. The first he identified as the primary or ionizable valence (Hauptvalenz) and the second as a secondary or non-ionizable valence (Nebenvalenz). In modern terms, Hauptvalenz and Nebenvalenz are equivalent to oxidation state and coordination number. This brought to an end the confusion between valence and stoichiometry that had bedevilled the development of the understanding of these compounds.

Werner then postulated that each element had preferred Hauptvalenz and Nebenvalenz values, leading to the concept of fixed coordination numbers for elements in given oxidation states. As a concrete example, we can take the luteo complex $\left[\mathrm{Co}\left(\mathrm{NH}_{3}\right)_{6}\right] \mathrm{Cl}_{3}$ and assign a Nebenvalenz (coordination number) of six and an Hauptvalenz (oxidation state) of three. In this first publication, he identified Nebenvalenz values of 6, 4 and 2 in the compounds $\left[\mathrm{Co}\left(\mathrm{NH}_{3}\right)_{6}\right] \mathrm{Cl}_{3}$ (Luteokobaltchlorid), $\left[\mathrm{Cu}\left(\mathrm{NH}_{3}\right)_{4}\right]\left(\mathrm{NO}_{3}\right)_{2}$ (Kupferammoniaknitrat) and $\mathrm{H}_{2} \mathrm{NHgCl}$, respectively. The replacement of ammonia by other ligands is explicitly identified in compounds such as $\left[\mathrm{Cr}\left(\mathrm{NH}_{3}\right)_{5}\left(\mathrm{H}_{2} \mathrm{O}\right)\right] \mathrm{Cl}_{3}$ and specifically identifies the presence of six, five and four coordinated ammonia ligands in a six-coordinate species in the luteo, purpureo and praseo complexes. In this first publication, he enclosed coordination entities in normal brackets, clearly identifying the coordinated ligands (Figure 11), although by his next publication he had started to use the square brackets that survive to this day [156].

$$
\begin{aligned}
& \left(\mathrm{Co}_{\mathrm{X}}^{\left(\mathrm{NH}_{3}\right)_{5}}\right) \mathrm{X}_{2} ; \quad\left(\mathrm{Cr}_{\mathrm{X}}^{\left(\mathrm{NH}_{3}\right)_{5}}\right) \mathrm{X}_{2} ; \quad\left(\mathrm{Ir}_{\mathrm{X}}^{\left(\mathrm{NH}_{3}\right)_{5}}\right) \mathrm{X}_{2} ; \quad\left(\mathrm{Rh}_{\mathrm{X}}^{\left(\mathrm{NH}_{3}\right)_{5}}\right) \mathrm{X}_{2} \\
& \text { Purpureokobaltsalze; Purpureo- Purpureoiridiumsalze; Purpureo- } \\
& \text { chromsalze; rhodiumsalze. }
\end{aligned}
$$

Figure 11. Werner initially used normal (curved) brackets to denote the coordination entity and stacking the ligands in a manner reminiscent of Jørgensen (Copyright Wiley. Used with permission) [149].

\subsection{Werner on Nomenclature}

Werner not only introduced a new model for describing the bonding and structure of coordination compounds, but also proposed a new scheme for their nomenclature and formulation which substantially persists to this day, and is the core of the IUPAC system for the nomenclature of these species. In 1897, Werner published his fifth article in the series concerning coordination compounds on the topic of their nomenclature "Beitrag zur Konstitution anorganischer Verbindungen. V. Mitteilung. Die Kobaltammoniakverbindungen und ihre Nomenklatur" (Contribution to the constitution of inorganic 
compounds. V. Communication. Cobalt-ammonia compounds and their nomenclature) [157]. The fully refined and mature version of his nomenclature is best found in his book "Neuere Anschauungen auf dem Gebiete der anorganischen Chemie" (New Ideas on Inorganic Chemistry) $[158,159]$ and it is instructive to quote his rules for coordination compounds in full [159]:

1. Names obtained from the colour of the compounds are to be avoided.

2. The name of the resulting complex is to be made up by placing side by side the names of the components.

3. The names of the atoms (or radicles) which are linked to the central metallic atom are to be placed before the name of this central atom. When carrying this out the following order is to be preserved: The names of the acid residues come first, then follow the names of the groups which resemble ammonia, and directly before the name of the metallic atom are to be placed the number of ammonia molecules.

4. The molecule of ammonia is to be expressed by the word ammine (spelt with a double $m$ ), in order to distinguish it from the organic amine. Water, after Palmaer's suggestion is expressed by aquo.

5. The names of the acid residues which are not in the first binding zone are placed after the name of the central metallic atom.

This is an additive nomenclature system in which ligands are given in the sequence anions (acid residues) before neutral ligands. Non-coordinated anions are placed after the metal name. The English translation [159] retained the German name construction, concatenating the cation and the anion, as in hexamminchrominitrate for $\left[\mathrm{Cr}\left(\mathrm{NH}_{3}\right)_{6}\right]\left(\mathrm{NO}_{3}\right)_{3}$ and diaquotetrammincobaltichloride for $\left[\mathrm{Co}\left(\mathrm{H}_{2} \mathrm{O}\right)_{2}\left(\mathrm{NH}_{3}\right)_{4}\right] \mathrm{Cl}_{3}$. For compounds with different coordinated ligands, stacked formulae or linear representations $\left(\left[(\mathrm{HO})_{2} \mathrm{Pt}\left(\mathrm{NH}_{3}\right)_{4}\right] \mathrm{Cl}_{2}\right)$ were used. Werner indicated the oxidation state by changing the ending of the metal component, a strategy that works in a satisfactory manner in German, where the anion is appended after the metal name, but not so well in English, where the tendency is to separate cation and anion. He proposed the modification of the element name with the following suffixes for oxidation states up to +8 :

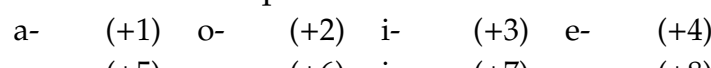

an- $(+5)$ on- $(+6)$ in- $(+7)$ en- $(+8)$

Thus, the oxidation state of +4 for the platinum in $\left[(\mathrm{HO})_{2} \mathrm{Pt}\left(\mathrm{NH}_{3}\right)_{4}\right] \mathrm{Cl}_{2}$ would lead to the name dihydroxotetrammineplatechloride. This aspect of the system was not to be sustained, but arguably persisted in names such as ferricyanide and ferrocyanide.

\section{Regulation and Regulations}

The basic principle which Werner adopted for naming coordination compounds is additive nomenclature, in which ligands are added as prefixes to the name of central (metal) atoms. This persists as the overriding principle in all subsequent refinements of nomenclature for coordination compounds. Excellent overviews of early developments have been given by Fernelius [160] and Bailar [161]. The following sections concentrate upon coordination compounds rather than general inorganic nomenclature.

Coming up to date, and with apologies to my good friends in IUPAC Division VIII, regulation can be seen as an ongoing and dynamic compromise between what is needed, what is wanted and what will be accepted! An example from terminology demonstrates this; in 1970 IUPAC termed chelating ligands with two donor atoms bidentate [162] but by 1990 this recommendation had been revised to didentate [163]. The change was proposed not on the basis of need or demand, but rather from the valid reason of seeking a single consistent set of numerical prefixes (mono, di, tri, etc.). The construction didentate opposes an earlier stated principle of not mixing Greek prefixes (di-) with words of Latin origin (dente, tooth) (although philological pedants could justify didentate on the basis of the Greek

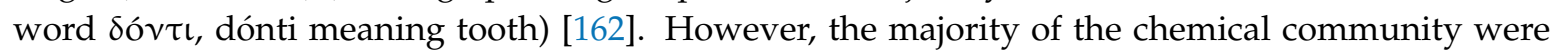
neither etymological experts, nor prepared to change a term they used and loved to one which was alien. Although this has many of the hallmarks of the arguments Jean Claude de la Métherie used against the de Lavoisier Méthode, the scientific opinion was clear; in the period 1990-2005, SciFinder topic 
searching gives 121 examples for the term didentate and 16,784 for the term bidentate (SciFinder, 22 July 2019). In 2005, IUPAC reverted to recommending bidentate because it "reflects common usage" [164]. Less controversial was the 2005 proposal that when anions with names ending in -ide are present in coordination entities, they should be denoted uniformly, and "without exception", by names ending -ido [164]. This affected long established usages such as chloro, fluoro, hydroxo and cyano; there was no rush of chemists to the nomenclature barricades, burning effigies of the IUPAC directorate, but rather a quiet acceptance that the changes were logical and could be lived with. Despite this, SciFinder topic searching only shows ten examples of the use of tetrachloridoplatinate since 2005, compared to 4595 citations using tetrachloroplatinate (SciFinder, 22 July 2019), so "living with" appears to equate with "ignoring". As an aside, one of the notable changes in chemical publishing is the loss of nomenclature by the journals. Until the mid 1990s, many journal editors very strictly corrected nomenclature to IUPAC recommended usage, a practice that has since fallen into disuse.

\subsection{Karlsruhe and the First Communion of Chemists}

Probably the first time that the international chemical community came together in a concerted effort to solve common problems was at the Karlsruhe Congress of 1860 [165-167]. Even the formula of a compound as simple as water was controversial [168]. William Higgins [169,170], John Dalton [171,172] and Grotthuss [173] all assumed the formula $\mathrm{HO}$, although the latter subsequently revised this to $\mathrm{HO}_{2}$ [174]. Incidentally, Dalton also proposed the formulae $\mathrm{HO}_{2}, \mathrm{HO}_{3}$ and $\mathrm{HO}_{4}$ for $\mathrm{HF}, \mathrm{HCl}$ and $\mathrm{Cl}_{2}$, respectively $[169,170]$. By the 1860s, the standard text books had differing formulations for water; in 1861 Kekulé was using $\mathrm{HO}$ [175-177] whilst by 1864 Lothar Meyer [178] had settled on $\mathrm{H}_{2} \mathrm{O}$. At the Karlsruhe meeting, Stanislao Cannizzaro called attention to the significance of the Avogadro hypothesis and clarified the differences between atomic weight, equivalent weight and molecular weight. Although the meeting did not explicitly discuss nomenclature, the acceptance and recognition of the Avogadro hypothesis lead directly to progress in periodicity, the periodic table and eventually to understanding the two- and three-dimensional structures of molecules.

\subsection{Paris and Geneva-Rules for Organic Chemistry}

Organic chemistry made enormous progress in the latter half of the 19th Century CE and the chemical community was beginning to suffer from an information overload. The first edition of Beilstein Handbook of Organic Chemistry published from 1883 onwards contained some 15,000 organic compounds $[179,180]$. By 1900, the number of known organic compounds was estimated to be 100,000. It was becoming barely, if at all, possible to read and follow all of the literature. Numerous new compounds and derivatives were being reported each month and the variety of names used, although often internally consistent within a research school or community, were not universally transferable or recognizable. The International Congress of Chemists met in Paris in July 1889 and in his opening remarks, Bertholet stated "...practical questions, such as ... nomenclature. The last urgently needs revision and improvement. The system hitherto followed has become insufficient. ... A new and clearer system is absolutely necessary, with lines broad enough to last for some time at least" [181]. The International Congress established an international commission to consider new nomenclature systems. This commission had 25 members responsible to a sub-committee of seven in Paris. This sub-committee met 45 times in the next two years to discuss the reports on the reform of organic chemistry nomenclature from the 25 experts. A report was presented to the Geneva meeting of the Congress in 1892 and, if nothing else, highlighted the differences among the various national approaches to nomenclature [182]. Perhaps the most important decision of the Geneva meeting was to establish a system of official names; "In addition to the usual name, every organic compound should be given an official name under which it may be found in indexes and dictionaries". This was an early recognition that nomenclature might have two different roles-those of communication and archiving. The Congress and the report only concerned itself with the nomenclature of organic compounds. An excellent account of the Congress is to be found in Crosland [33]. 
With the nomenclature of organic compounds off to a good start, we will now concentrate upon the development of nomenclature for inorganic materials, with the emphasis upon coordination compounds.

\subsection{Neologisms and New Terminology}

At this point it is appropriate to make a slight deviation into two aspects of terminology which emerged in the early part of the 20th century CE. We have used the term ligand throughout this text, but this was a word and concept that was unknown to Werner and Jørgensen [183]. The word ligand was first used by Alfred Stock in 1917 to describe the groups bonded to silicon (or carbon) and had its roots in the discussions and lack of clarity regarding the precise meaning of valence [184]. "Ligand" was used in this sense intermittently in the following years but was not widely embraced by the chemical community. An early use of the word ligand in coordination chemistry in its modern sense seems to date to 1926, when Klement published a paper entitled Phosphorsäure als Ligand in komplexen Kobaltverbindungen (Phosphoric acid as a ligand in cobalt complexes) [185] in 1926 and by 1935 Jensen [186] had introduced the term to the broader European community. By 1939, Tutida (Tsuchida) and Tamaki were using it routinely in discussions of coordination compounds [187-192]. The term was slowly adopted by the community and was "formalized" by IUPAC in the formulation [193] of the tentative [194,195] and definitive [196] 1957 IUPAC recommendations for the nomenclature of inorganic chemistry. A complete discussion of the etymological and scientific history of the word ligand is given in Reference [183].

The second word introduced into coordination chemistry early in the 20th century CE, and one which is so engrained in our modern understanding that we tend to imagine that it has always been there, is chelate (or chelation) [197]. However, this is another word that was unknown to Werner and his contemporaries even though they worked with bidentate ligands such as ethane-1,2-diamine. Multidentate ligands have played a crucial role in the development of coordination chemistry, but it was only in 1920 that the word chelate was first introduced. In a paper on pentane-1,3-dionate complexes, Morgan and Drew [198] used the word chelate to describe a ligand which bound to a metal ion through two different atoms. The new word was introduced thus, "The adjective 'chelate,' derived from the great claw or 'chela' ('chely') of the lobster and other crustaceans, is suggested for these caliper-like groups which function as two associating units and fasten on to the central metallic atom so as to produce heterocyclic rings." The concept of chelation was not accepted uncritically by the chemical community. Although Lowry made early reference to the term chelate in a 1923 article entitled "Stability of co-ordination compounds" [199], he also introduced the terms cyclic and centric co-ordination to distinguish between conjugated and non-conjugated chelate rings. This was robustly dismissed in a polemical article by Smith later in the same year, who also commented on the special stability of the five-membered chelate ring [200]; Lowry responded to the criticism in an article debating the precise "crabbiness" with which the term chelate should be used [201].

\subsection{Preliminary Activities on Inorganic Nomenclature}

The need for a more systematic approach to the nomenclature of inorganic compounds was recognized early in the 20th century $\mathrm{CE}$, being initially identified in the main group community where ever more oxyacids and their salts were being isolated and characterized. Responding to 1910 proposals for the nomenclature of acid phosphates by McKenney [202], Ransom made the following plea, "Has not the time come for scientific men to be exact and scientific in the matter of chemical nomenclature, and to demand of manufacturers the use of names which shall indicate the composition of the material designated?" [203].

The modern story begins in 1911, with the establishment of the International Association of Chemical Societies (Association Internationale des Sociétés Chimiques, IACS), which met in Paris and identified the need for a rationalization of the nomenclature of inorganic and organic chemistry and established three committees for inorganic nomenclature, organic nomenclature and unification of the 
methods of notation of physical constants [204,205]. The first reports of the committees were planned for the meeting in Berlin in 1912 [206]. External events intervened and the work of IACS, especially international collaboration, was essentially brought to an end with the outbreak of the first world war in 1914. The IACS became one of the casualties of the global conflict and the association was dissolved in 1919.

The International Union of Pure and Applied Chemistry (IUPAC) was established in 1919 as an organization with a remit including nomenclature, but broader than IACS [207]. The original membership of IUPAC excluded the nations of the Central Powers (Germany, Austria-Hungary, Ottoman Empire and Bulgaria), following decisions of the Interallied Scientific Academies in 1918 [208].

An interesting overview of the state of chemistry just after the establishment of IUPAC is found in James Walker's presidential address to the Chemical Society in 1923, where he discussed the evolution of symbols and formulae in chemistry and highlighted just how fragmented and fragmentary the understanding of bonding, molecular structure and valence was less than 100 years ago [209].

The nomenclature proposals for coordination compounds from Werner were widely accepted, although he had concerned himself more with complex cations than anions. By 1923 the Nomenclature Committees of both the British and the American Chemical Societies [210] had taken up the nomenclature challenge and recommended that compounds such as $\left[\mathrm{PtCl}_{4}\right]^{2-}$ and $\left[\mathrm{PtCl}_{6}\right]^{2-}$ should be named as coordination entities (ligand first, metal last, suffix indicating charge and oxidation state) with the names chloroplatinite and chloroplatinate, respectively, "Salts of chloroplatinic acid are chloroplatinates (not platinichlorides). Similarly salts of chloroauric acid are to be called chloroaurates". Although this differs from modern practice in a number of details (no oxidation number, -ite or -ate ending to indicate oxidation state, no indication of the number of chloride ligands) the trend was towards a common system for coordination entities regardless of charge. We note in passing that the -ite and -ate system of naming anions and the parent -ous or -ic endings for cations works well if only two oxidation states are commonly encountered, but suffer from the disadvantage even in these cases, that the oxidation state and coordination number are not given. Thus, the name chloroplatinite only leads to the correct formulation if one knows the oxidation state and coordination number; with knowledge of only oxidation state, $\left[\mathrm{PtCl}_{3}\right]^{-}$or $\left[\mathrm{PtCl}_{4}\right]^{2-}$ would be equally acceptable.

The activities of the US and UK national chemical societies were linked to the decision of the newly formed IUPAC in 1921 to establish a commission for inorganic nomenclature [211]. The first reports on inorganic nomenclature came in fragmentary form from 1926 onwards from Marcel Delépine, but these had little to say regarding coordination compounds [212]. The fullest version of the report seems to have been published in 1929 [213], which includes the international responses to the consultation document. To extract some of the more important points, there is a suggestion to use oxidation numbers (Stock numbers in the nomenclature of the time) to indicate oxidation state, in the form "iron II" or "iron III". This was in direct response to the difficulties of using the Werner modifications to the metal root to indicate oxidation state in languages other than German. Where specifics of coordination chemistry are mentioned, the report goes against some of the proposals of Werner and the 1923 recommendations from the chemical societies. Although examples of constructed names are given in French, the recommendation is to place the metal as the first part of the constructed name for both anions and cations. More confusingly, the recommendation included changing the name of the ligand, depending on the overall charge of the complex, as seen in the example given of $\left[\mathrm{Co}\left(\mathrm{NH}_{3}\right)_{2}\left(\mathrm{NO}_{2}\right)_{4}\right]\left[\mathrm{Co}\left(\mathrm{NH}_{3}\right)_{4}\left(\mathrm{NO}_{2}\right)_{2}\right]$ which is named cobalti-diammonio-tétra-nitrite-cobalti-dinitro-tétrammonique and conforming to the French convention of naming the anion before the cation. Note the different nomenclature of the $\mathrm{NH}_{3}$ ligands; ammonio in the anion and ammonique in the cation. A specific recommendation for the incorporation of oxidation (Stock) numbers into English names is found for $\mathrm{K}\left[\mathrm{Cr}\left(\mathrm{NH}_{3}\right)_{2}\left(\mathrm{NO}_{2}\right)_{4}\right]$ which is named potassium chromium-III-diammonio-tetranitrite. Germany was excluded from IUPAC membership until 1929 and the German Chemical Society established a parallel commission on inorganic nomenclature that made an intermediate report recommending the use of oxidation (Stock) 
numbers rather than the Werner system to indicate oxidation state [214]. The kerning in the German article is rather unclear but the preferred form seems to be Osmium(VIII)oxyd. There was nothing more regarding coordination compounds, "Die Kommission hat sich bisher erst mit einigen Fragen von allgemeiner Bedeutung beschaftigt ohne das gesamte Gebiet erschopfend zu behandeln" (The Commission has so far only dealt with a few issues of general importance without exhaustively covering the whole area). After a subsequent intermediate report [215], the final recommendations only appeared in 1937 in French [216] and English [217] but not German.

An excellent perspective of the convoluted history of nomenclature between 1925 and the 1940 rules has recently been published by Leigh [218].

\subsection{Rules for Naming Inorganic Compounds 1940}

The first official recommendations for nomenclature of inorganic compounds from the International Union of Chemistry (see Reference [204] for a discussion of the name changes that IUPAC and allied organizations experienced in the 20th century CE) saw the light of day as the world was descending once again into chaos. It is a remarkable tribute to the commitment of the international scientific community involved in this work, that their efforts came to fruition. In view of the international situation, that was worsening on a daily basis, the report was published in a series of national journals. A short report appeared in the Analyst [219] and the full documentation was published in Berichte der Deutschen Chemischen Gesellschaft [220], Helvetica Chimica Acta [221,222], Journal of the Chemical Society [223] and Journal of the American Chemical Society [224]. The bulk of the document is concerned with general aspects of inorganic nomenclature, and coordination compounds are only dealt with in one short (half page) section entitled Higher order compounds. The recommendation is to basically follow the Werner system, subject to the introduction of oxidation (Stock) numbers to indicate oxidation state, giving examples such as potassium hexacyanidoferrate(II) and potassium hexacyanidoferrate(III) for $\mathrm{K}_{4}\left[\mathrm{Fe}(\mathrm{CN})_{6}\right]$ and $\mathrm{K}_{3}\left[\mathrm{Fe}(\mathrm{CN})_{6}\right]$, respectively. Coordination compounds are mentioned elsewhere in the document and one point in which the 1940 recommendations differ from later proposals is in the use of shortened forms of names. The rules state, "In the case of systematic names it is not always necessary to indicate stoicheiometric proportions in the names unless there is some special reason for doing so, because a glance at the formula shows at once the quantitative and atomic composition", and give examples "Potassium chloroplatinate instead of potassium hexachloroplatinate(IV). Potassium cyanoferrate(II) instead of potassium hexacyanoferrate(II). Potassium cyanoferrate(III) instead of potassium hexacyanoferrate(III)". Today, potassium chloroplatinate is, at best, ambiguous and the 1940 usage implies the use of potassium chloroplatinite for $\mathrm{K}_{2}\left[\mathrm{PtCl}_{4}\right]$. The use of oxidation (Stock) numbers to indicate oxidation state was explicitly proposed, together with a recommendation to discontinue the use of the established -ic and -ous nomenclature; "The system of valency indication by terminations such as -ous, -ic (ferrous, ferric) which was previously in use has proved unsatisfactory and should now be avoided".

The proposed name of potassium hexanitrocobaltiate(III) for $\mathrm{K}_{3}\left[\mathrm{Co}\left(\mathrm{NO}_{2}\right)_{6}\right]$ in the UK version [220] is revised in the US version to potassium hexanitrocobaltate [221].

The sequence of ligands in the name is to be in the order (i) acidic groups such as chloro, cyano, cyanato, thiocyanato, sulfato, nitro, nitrito, oxalato and hydroxo; (ii) neutral groups: aquo, substituted amines and last of all ammine. The UK publication is also inconsistent in the use of hyphenation, with the recommendation of hexa-aquochromium(III) chloride as the name for $\left[\mathrm{Cr}\left(\mathrm{OH}_{2}\right)_{6}\right] \mathrm{Cl}_{3}$, whereas the US version uses hexaaquochromium(III) chloride.

The American Chemical Society held a symposium on inorganic chemical nomenclature at its 101st annual meeting in St. Louis in 1941. This meeting recognized the importance of the work of the IUPAC commission, "History will hardly record the year 1940 as one of general progress in international cooperation, but nevertheless this 1940 Report ... is a giant stride towards improved and internationally standardized nomenclature in the field of inorganic chemistry. Nothing so important along this line has happened since the work done by Berzelius beginning in 1811 in extending the 
system of nomenclature which was introduced in 1787 by Guyton de Morveau and Lavoisier and which has stood the test of time in remarkable manner" [225]. Nevertheless, it was early recognized that the 1940 proposals were limited and not entirely internally consistent in their discussion of coordination compounds and that important areas, such as stereochemistry, were completely ignored [222].

\subsection{The 1951 ACS Symposium}

In 1951, on the occasion of the diamond jubilee of the American Chemical Society, a Symposium on Chemical Nomenclature took place at the 120th meeting in New York. Although there had been many conferences concerned with the mechanics and formulation of chemical nomenclature, this was the first symposium concerned with the philosophy and underlying structure. The proceedings of the symposium were published as the ACS Advances in Chemistry Series in 1953 and this volume is a valuable resource to anyone interested in the early history of chemical nomenclature [226]. Of particular relevance are the chapters entitled "Some General Principles of Inorganic Chemical Nomenclature" by Bassett [227] and "Nomenclature of Coordination Compounds and Its Relation to General Inorganic Nomenclature" by Fernelius [228].

\subsection{The 1953 Proposals}

A first revision of the 1940 proposals appeared in 1953 as a set of tentative rules [229]. These tentative rules, which included the proposal to replace the halo- names for ligands by halido-, received much comment and discussion at IUPAC annual meetings and resulted in the acceptance of a final version as the 1957 rules.

\subsection{Nomenclature of Inorganic Chemistry. 1957 Rules}

The next IUPAC recommendations for the nomenclature of inorganic compounds date from 1957 [230] and are most readily accessed in the slightly modified form published for the North American community [231] and in Cahn's book An Introduction to Chemical Nomenclature [232]. The document is very much a vision of inorganic chemistry in flux. On the one hand, it contains a number of proposals which might be linguistically and logically justified, but which never achieved any acceptance. These include the recommendations to use wolframate and nickelate for anions, rather than tungstate and nickelate. The canonical publication [227] recommends the use of oxidation numbers (sodium tetracarbonylferrate(-II) for $\left.\mathrm{Na}_{2}\left[\mathrm{Fe}(\mathrm{CO})_{4}\right]\right)$, whereas the US version [228] favours the additional use of charge numbers (sodium tetracarbonylferrate(2-)), more in accord with modern practice, although -ic and -ous were retained for elements with only two oxidation states.

The section on coordination (written coördination) compounds is relatively short. Nevertheless, the principles are clearly stated: in formulae, the central atom symbol should be first, followed sequentially by anionic and neutral ligands. In names, the central atom is to be placed after the ligands. The canonical form [227] prescribes that the anionic ligands were to be cited in the order $\mathrm{H}^{-}>$ $\mathrm{O}^{2-}>\mathrm{OH}->$ monatomic anions $>$ polyatomic anions according to a priority list $>$ organic anions in alphabetical order, whereas the US version [228] prefers to place hydride at the end of the formula and to impose a strict alphabetic sequence within monoatomic and polyatomic anions. Similarly, the original publication cites neutral ligands in the sequence $\mathrm{H}_{2} \mathrm{O}>\mathrm{NH}_{3}>$ inorganic ligands according to a priority list $>$ organic ligands in alphabetical order, whereas the US version prefers alphabetical order for inorganic ligands. The priority list mentioned can be seen as the origin of the "snake table" that appears in the 1970 recommendations. Anionic ligands should be indicated with the ending -ido, but with exceptions including fluoro, chloro, bromo, iodo, oxo and hydroxo. The US version wanted more exceptions (hydroxy, methoxy, hydro, etc.) to be added to the list of anionic ligands.

In tentative rules, IUPAC had proposed using aqua for water ligands. However, the power of conservatism should not be underestimated and by the definitive rules, "However, as the old form [aquo] is so widely used, many regarded the change as too pedantic, and the Commission has decided to retain 'aquo' as an exception." The US version explicitly prohibits the use of elisions in names: i.e., 
hexaaquocobalt(III) not hexaquocobalt(III). The canonical version is less clear and appears to allow the elision. In complexes with multidentate ligands, the coordinated atoms were indicated with suffixes, for example (dithioöxalato-S, $S^{\prime}$ ).

The 1957 rules do not really address stereochemistry beyond the use of the prefixes cis-, trans-, sym- and asym-.

\subsection{Nomenclature of Inorganic Chemistry. 1970 Rules}

The 1970 Red Book [233] is a rather strange document, representing a scientific world which was changing rapidly as new techniques and new classes of compounds were being discovered, but at the same time being based upon a document predating 1957 with its own roots in the chemistry of the early 20th century CE. For example, the use of oxidation states is fully in accord with modern usage (2.2.5.2 iron(III) chloride for $\mathrm{FeCl}_{3}$ ) but at the same time the name ferrum(III) chloride (which to the best of my knowledge has never been used by the scientific community) persists from the 1957 rules and is given equal validity. The recommendations do not attempt to make a preference among the use of oxidation number, charge number or explicit identification of the number of counterions, a philosophy that continues to this day. Thus, $\mathrm{K}_{3}\left[\mathrm{Fe}(\mathrm{CN})_{6}\right]$ could be named potassium hexacyanoferrate(III), potassium hexacyanoferrate(3-) or tripotassium hexacyanoferrate (but not apparently potassium ferricyanide). The rules explicitly stated that elisions should not be used (pentaammine not pentammine), a naming principle that is also retained.

An important definition was that the sequence of ligands in names was to be purely alphabetical (ignoring numerical prefixes or charges on the ligands). The sequence within a formula was to be central atom, followed by anionic ligands and finally neutral ligands. Interestingly, the report did not accept and include the proposal to replace the ligand names chloro, fluoro, etc. with the initially proposed chlorido- fluoride, etc. This would have to wait another 35 years for the 2005 recommendations.

For multidentate ligands, coordination modes were indicated with suffixes, for example glycinato$\mathrm{O}, \mathrm{N}$ for chelating glycinate and glycine- $\mathrm{N}$ and glycine- $\mathrm{O}$ for $\mathrm{N}$ and $\mathrm{O}$-bound glycine, respectively. The rules also began to address the nomenclature challenges of organometallic compounds.

The 1970 rules also began to address the question of stereochemical nomenclature beyond simple cisand trans-prefixes, although the approach was to be significantly revised in the 1990 recommendations.

The 1970 Red Book also consistently used sulfur (rather than sulphur) as an element name and as the parent for derived species such as sulfides and sulfates [234-236]. Neither the English scientific community nor the general lexicographic community have fully accepted that the correct, and only, spelling is sulfur.

\subsection{Nomenclature of Inorganic Chemistry. Recommendations 1990}

In 1978, the IUPAC Commission of Nomenclature on Inorganic Chemistry (CNIC) initiated a project for a new, two volume edition of the Red Book to replace the 1970 rules. Formally, the 1970 Recommendations are catalogued as the second edition of the 1957 rules. Part I of this was published as the Nomenclature of Inorganic Chemistry. Recommendations 1990 [237]. This volume was a major revision, but a number of aspects can be identified which directly impacted coordination chemistry. The first was a terminology point, to refer to oxidation numbers and charge numbers rather than Stock numbers and Ewens-Bassett numbers in names (1990 flavour) such as vanadium(IV) oxide sulfate and tetraoxosulfate(2-) for $\mathrm{VOSO}_{4}$ and $\left(\mathrm{SO}_{4}\right)^{2-}$ respectively. Another issue of terminology was the use of didentate and tridentate to replace the more established bidentate and terdentate (vide infra).

The grammar and parsing of names and formulae resembled the 1970 rules. The sequence of ligands in names was to be purely alphabetical (ignoring numerical prefixes) and independent of the charge on the ligands. In contrast, the sequence within a formula was to be central atom, followed by anionic ligands and finally neutral ligands. This resulted in the minor paradox of the compound with formula $\left\{\mathrm{CoCl}\left(\mathrm{NH}_{3}\right)_{5}\right\} \mathrm{Cl}_{2}$ being named pentaamminechlorocobalt(III) chloride or pentaamminechlorocobalt $(2+)$ chloride. It is of note that the recommendations (a change from the 
"rules" of 1970) include an extended section on the use of stereochemical descriptors for coordination compounds introducing the polyhedral symbol notation (I-10.5 to I-10.7) and also introduce the kappa-notation to identify the atom or atoms through which a ligand is bound to a metal or metals within a coordination entity (I-7.3.3.2 Note 7p).

\subsection{Nomenclature of Inorganic Chemistry II. Recommendations 2000}

In 2000, a second volume of recommendations, entitled Nomenclature of Inorganic Chemistry II. Recommendations 2000 was published [238]. This document primarily addressed areas of nomenclature which had not been covered in the 1990 recommendations. The chapters of most relevance to coordination chemistry concerned metal complexes of tetrapyrroles (Chapter II-3) and regular single-strand and quasi single-strand inorganic and coordination polymers (Chapter II-7). Many of the recommendations in Chapter II- 3 were revised in the 2005 document, where the naming of the parent deprotonated tetrapyrrole ring system was changed to reflect usage in the recommendations for organic chemistry. Coordination networks and polymers are highly topical, and the initial recommendations highlighted the complexity of these systems and illustrated that names with a high information content could not always be easily deconstructed to regenerate the structures. Much of the discussion centres upon the identification and naming of a constitutional repeating unit, which is essential in the generation of a name that is both unambiguous and unique. In particular, the discussion of coordination polymers is rewarding and thought provoking as it identifies the need for numbering systems in polynuclear systems (and indeed in bridging ligands) as well as the philosophical discussions of how to deal with ligands where the parent name changes as a result of coordination. This latter topic is under active discussion in IUPAC committees where the nomenclature consequences of desymmetrization are an active, often heated, area of debate. It seems likely that many of the recommendations will be modified in the context of a final set of proposals regarding the use of the k-nomenclature.

\subsection{Nomenclature of Inorganic Chemistry. IUPAC Recommendations 2005}

The 2005 edition of the Red Book is the most recent (as of July 2019) and contains the recommendations currently supported and endorsed by IUPAC [164]. One of the important features of the 2005 publication is the clear recognition (IR-1.4) that nomenclature has multiple roles and that "Few chemists want to use such a degree of sophistication every time they refer to a compound, but they may wish to do so when appropriate". As far as coordination compounds were concerned, there were a number of changes in the 2005 recommendations.

As mentioned earlier, one significant change (IR-1.6.4, IR-7.1.1, IR-9.2.2.3) is that in coordination entities, "anion names ending in '-ide', '-ite' and '-ate', respectively, are changed to end in 'ido', 'ito' and 'ato', respectively". The historically allowed ligand forms, fluoro, chloro, bromo, iodo, hydroxo, hydro, cyano, oxo, etc. were replaced by fluorido, chlorido, bromido, iodido, hydroxido, hydrido, cyanido, oxido, etc. Also recommended were changes to ligands predicated by other changes to inorganic or organic nomenclature, such as naming coordinated ${ }^{-} \mathrm{HNNH}^{-}$species as hydrazine-1,2-diido ligands (IR-1.6.2). The change of nomenclature of $\mathrm{HNCO}^{\bullet-}$ ligands from (hydridonitrido)oxidocarbonate( $\left.\bullet 1-\right)$ to (hydridonitrato)oxidocarbonate $(\bullet 1-)$ is equally logical, but neither name immediately suggests the formula of the radical to this author. One recommendation that is significantly different to established practice relates to porphyrin ligands, where the previously proposed ligand name porphyrinato(2-) should be replaced by porphyrin-21,23-diido. It is unclear whether this latter change has been embraced by the relevant community.

Another important, and long overdue, change was to the sequence of ligands in formulae. The new recommendation was to order ligands, without exception, alphabetically according to abbreviation or formula. This replaces the earlier recommendations to have the anionic ligands first. This was often difficult in cases of non-innocent ligands or organometallic compounds. The abbreviation of the ligand is, of course, something of a grey area, although a list of recommended abbreviations is presented in Table VII of the IUPAC Recommendations 2005 [164]. Thus, the formula of Zeise's salt should be 
written $\left[\mathrm{Pt}\left(\eta^{2}-\mathrm{C}_{2} \mathrm{H}_{4}\right) \mathrm{Cl}_{3}\right]^{-}$, on the basis that $\mathrm{C}$ precedes $\mathrm{Cl}$ alphabetically, but the sequence would be inverted in $\left[\mathrm{PtCl}_{3}\left(\mathrm{H}_{2} \mathrm{C}=\mathrm{CH}_{2}\right)\right]^{-}$. The new ordering also has some unexpected consequences, leading to the formulations $\left[\mathrm{Ru}(\mathrm{en})_{2} \mathrm{~F}_{2}\right],\left[\mathrm{RuCl}_{2}(\mathrm{en})_{2}\right],\left[\mathrm{RuBr}_{2}(\mathrm{en})_{2}\right]$ and $\left[\mathrm{Ru}(\mathrm{en})_{2} \mathrm{I}_{2}\right]$ (en = ethane-1,2-diamine) within a closely related series of compounds.

\subsection{The "Brief Guide", 2015-2017}

In 2015, IUPAC recognized that although all inorganic chemists should read the 366 pages of the Red Book, very few would, and issued a document entitled "Brief guide to the nomenclature of inorganic chemistry" in which the essentials of inorganic nomenclature were summarized [239]. This has subsequently been made available online as a "living" .pdf document, currently in version 1.3 from November 2017 [240]. This is an invaluable document and also provides a readily accessible version of the "snake table", which determines element sequences in names and formulae. This document has been recently incorporated in a leading text-book of inorganic chemistry [241].

This review has concentrated upon the recommendations and implementation of inorganic nomenclature in the anglophone community. The differing structures in other languages have been mentioned in the text, but linguistic differences, ranging from a different script to differing names form the elements, should not be underestimated. In this context, it is important to note that the Brief Guide is available in multiple languages [242], including Basque, Danish, Dutch, French, Galician and Spanish. I also note that these difficulties do not arise in structure-based computer-readable chemical information systems.

\subsection{Quo Vadis?}

Coordination chemistry is not a dead science but is continuously evolving and generating new challenges in structure and bonding. Interactions between metals and ligands are at the core of much supramolecular chemistry and nanoscale chemistry. To date, nomenclature systems are struggling to accommodate the interactions between discrete molecules that characterize supramolecular chemistry into their systematics.

In coordination chemistry, ion-pairing is known to be of great importance in both the solid state and solution, and a future challenge might be to incorporate descriptions of hydrogen-bonding interactions between anions and cations into the naming protocols.

Similarly, new structural types generate new challenges. The description of the $[\mathrm{AuXe} 4]^{2+}$ ion as tetraxenonidogold(2+) (IR-9.2.2.2 in Reference [164]) appears to imply the presence of xenon(1-) ligands and formulation as a gold(VI) complex, although the compound is reported as a gold(II) complex [243]. In this case, the formality of the nomenclature appears to be generating a name with incorrect information content. A more correct name might be tetraxenongold(2+).

Another area in which guidance from IUPAC might be welcomed is in the nomenclature of "simple" anions. This is still known as hexafluorophosphate to most chemists, but current recommendations are hexafluoro- $\lambda^{5}$-phosphanuide or hexafluoridophosphate(1-). The latter might be preferred for coordination compounds on the basis that both ions are named as coordination entities, but would have the corollary that the $\mathrm{SO}_{4}{ }^{2-}$ and $\mathrm{ClO}_{4}{ }^{-}$salts should be named as tetraoxidosulfate(2-) and tetraoxidochlorate(-) respectively. Clarification on the use of square brackets or parentheses for anions of this type would also be useful.

A real challenge to be addressed are the consequences for nomenclature arising from changes in the ligand or loss of symmetry in coordination events. The basic principle of additive nomenclature is the concatenation of the ligand names with the metal centre(s) in the coordination entity. This implies that the name of the ligand should reflect the name of the parent species. However, changes in symmetry can also change the preferred name of the parent, with isotopic labels being a simple case. 


\section{Final Thoughts on "the Naming of Complexes"-With Apologies to T.S. Eliot}

\subsection{Why Bother Naming Things?}

Chemical nomenclature has three primary functions: to identify compounds in normal dialogue, to identify compounds uniquely in scientific output and to allow unique identification of materials in databases and repositories for both industrial and scientific application. The identification of a compound in a unique manner, either as a pure species or as a component in a formulation, is critical in the definition and protection of intellectual property. All three of these functions may overlap but have some exclusivities. Only in the latest incarnation of the "Blue Book" for organic compounds has IUPAC fully implemented so-called PINs to indicate preferred IUPAC nomenclature; a PIN is a unique name for a chemical substance which is preferred over other possible names generated by IUPAC nomenclature rules [136]. Nevertheless, it is rather unlikely that the PINs propan-2-one and trichloromethane will replace acetone and chloroform in the near future in either the general laboratory vocabulary or in the wider population. In our own research, we work on a daily basis with a compound which our publications describe with the systematic name $\left[\left(6,6^{\prime}\right.\right.$-dimethyl[2,2' -bipyridine]-4,4'-diyl)di(4,1-phenylene) $]$ bis(phosphonic acid) (Figure 12a). Nevertheless, the compound is always referred to in the laboratory as ALP1 (anchoring ligand phosphonic acid 1-phenylene spacer), with a gratuitous reference to a certain range of mountains in Switzerland.

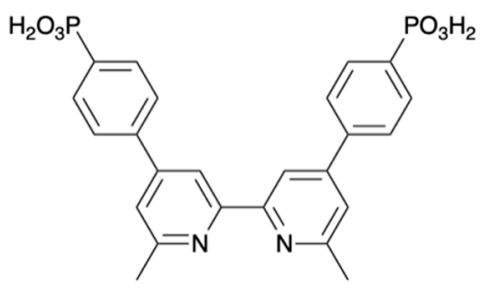

(a)

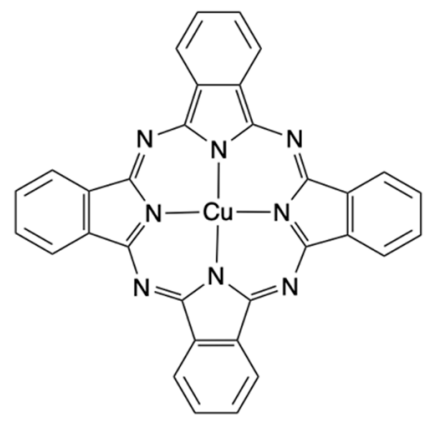

(b)

Figure 12. (a) The structure of the compound $\left[\left(6,6^{\prime}\right.\right.$-dimethyl[2,2'-bipyridine $]-4,4^{\prime}$-diyl $)$ di $(4,1$ phenylene)]bis(phosphonic acid), known to its friends as ALP1 and (b) the structure of phthalocyanine29,31-diidocopper(II).

\subsection{The IUPAC International Chemical Identifier (InChI)}

One approach which has great promise is to replace names in depositories and databases by metadata which is more appropriate. The IUPAC is also a pioneer in this area, developing the International Chemical Identifier (InChI). An InChI is human-readable (with difficulty) and machine readable and contains all information regarding atoms and their bond connectivity, tautomeric information, isotope information, stereochemistry and electronic charge. Often, the $\mathrm{InChI}$ is converted to an InChI key, which is not human-readable. The InChIs for trichloromethane and propan-2-one are $1 \mathrm{~S} / \mathrm{CHCl} 3 / \mathrm{c} 2-1(3) 4 / \mathrm{h} 1 \mathrm{H} / \mathrm{i} 1 \mathrm{D}$ and $1 \mathrm{~S} / \mathrm{C} 3 \mathrm{H} 6 \mathrm{O} / \mathrm{c} 1-3(2) 4 / \mathrm{h} 1-2 \mathrm{H} 3$, respectively. The corresponding InChI keys are HEDRZPFGACZZDS-UHFFFAOYSA-N and CSCPPACGZOOCGX-UHFFFAOYSA-N, respectively. With more complicated structures, such as ALP1 in Figure 12a, neither the InChI (InChI=1S/C24H22N2O6P2/c1-15-11-19(17-3-7-21(8-4-17)33(27,28)29)13-23(25-15)24-14-20(12-16(2)2624)18-5-9-22(10-6-18)34(30,31)32/h3-14H,1-2H3,(H2,27,28,29)(H2,30,31,32)) nor the InChI key (KQAAQ RWJGPMABM-UHFFFAOYSA-N) are far from easy for human beings to interpret.

At present, there are no PINs for inorganic and coordination compounds and so a multiplicity of nomenclature is likely to persist in the "real world". Machine readable alternatives, such as InChI, still need to be fully implemented for inorganic systems in general, and coordination compounds in 
particular. Nevertheless, there is a need for the unique and unambiguous identification of coordination compounds in the regulatory environment. The European REACH legislation (Registration, Evaluation, Authorisation and Restriction of Chemicals) controls chemicals which are imported, prepared or used by industry in a quantity of one tonne $(1000 \mathrm{~kg})$ or greater per year [244].

The need for a unique identification is readily seen with the compound phthalocyanine-29,31diidocopper(II) (Figure 12b), which is produced in 5000-25,000 tonne per year quantities in the United States alone, is used as a catalyst, semiconductor, dye and as a pigment, and is sold under names including: copper phthalocyanine, cuprolinic blue, cupromeronic blue, Monastral Blue B, Monastral blue dye, Monastral Fast Blue, phthalocyanine blue, Heliogen Blue LBG, Heliogen Blue NCB, Heliogen Blue BNC, Heliogen Blue BWS, Heliogen Blue IBG, Heliogen Blue BV, Heliogen Blue WX, Indolen Blue 3G, Blue Toner GTNF, Ceres Blue BHR, Cyan Blue GT, Cyanine Blue Bnrs, Cyanine Blue LBG, Calcotone Blue GP, Chromatex Blue BN, Helio Blue B, Linnol Blue KLG, Lionol Blue ER, Lionol Blue KLG, Fastogen Blue BS, Fastogen Blue FP, Fastogen Blue GR, Fastogen Blue GS, Graphtol Blue BL, Heliogen Blue BR, Heliogen Blue K, Cyanine Blue BB, Cyanine Blue BF, Cyanine Blue C, Cyanine Blue HB, Lumatex Blue B, Cyanine Blue Rnf, Bahama Blue BC, Bahama Blue BNC, Bahama Blue WD, Copper(II) phthalocyanine, MFCD00010719, C.I. Pigment Blue 15, Aqualine Blue, Fastolux Blue, Bermuda Blue, Fastogen Blue B, Heliogen Blue A, Heliogen Blue B. Furthermore, the compound exists in a number of polymorphs which have different solubility and reactivity.

As a final comment, one should ask whether nomenclature is a book-keeping exercise, a robust intellectual framework for developing and extending understanding or even a driver for new research directions.

This short article has attempted to show that nomenclature provides a platform for the understanding of chemistry and a drive for developing models to explain new phenomena. Nevertheless, sometimes nomenclature itself can be a driver. I strongly suspect that studies into the higher oxidation state of krypton might have been motivated by the search for kryptic acid [245]!

Acknowledgments: The author would like to thank the Universitätsbibliothek Basel for support and assistance in locating some of the more obscure historical publications. I would also like to thank the members of IUPAC Division VIII for explicit comments on drafts of this manuscript as well as more general discussions on the ramifications of nomenclature. Finally, I would like to thank Antonio Loprieno for checking some of my translations and Anton Bierl for helpful discussions on the distinctions between copper and bronze in the Homeric period.

Conflicts of Interest: The author has no conflict of interest to declare. The opinions in this manuscript are those of the author alone and do not represent those of the IUPAC Division VIII Chemical Nomenclature and Structure Representation.

\section{References}

1. Graham, L. The power of names: in culture and in mathematics. Proc. Am. Philos. Soc. 2013, 157, $229-234$. Available online: https://www.jstor.org/stable/24640241 (accessed on 4 August 2019).

2. Graham, L. The power of names. Theol. Sci. 2011, 9, 157-164. [CrossRef]

3. West, A. The rules for longs. TUGboat 2011, 32, 47-55. Available online: https://www.tug.org/TUGboat/tb32 -1/tb100west.pdf (accessed on 4 August 2019).

4. CAS Source Index (CASSI) Search Tool. Available online: https://cassi.cas.org/search.jsp (accessed on 14 July 2019).

5. Kauffman, G.B. General historical survey to 1930. In Comprehensive Coordination Chemistry; Wilkinson, G., Gillard, R.D., McCleverty, J.A., Eds.; Pergamon Elsevier: Oxford, UK, 1987; Volume 1, pp. 1-20.

6. Kauffman, G.B. Coordination chemistry: history. In Encyclopedia of Inorganic Chemistry; Scott, R.A., Ed.; Wiley: New York, NY, USA, 2006.

7. Orna, M.V. The Chemical History of Color; Springer: Heidelberg, Germany, 2013.

8. Singh, H.B.; Bharati, K.A. (Eds.) Mordants and their applications. In Handbook of Natural Dyes and Pigments; Woodhead Publishing India: New Delhi, India, 2014; pp. 18-28.

9. Abel, A. The history of dyes and pigments: From natural dyes to high performance pigments. In Colour Design; Best, J., Ed.; Woodhead Publishing Elsevier: Duxford, UK, 2012; pp. 557-587. 
10. Ferreira, E.S.B.; Hulme, A.N.; McNab, H.; Quye, A. The natural constituents of historical textile dyes. Chem. Soc. Rev. 2004, 33, 329-399. [CrossRef] [PubMed]

11. Bucklow, S. Red: The Art and Science of a Colour; Reaktion Books: London, UK, 2016.

12. Libavius, A.D.O.M.A. Commentationum Metallicarum Libri Quatuor de Natura Metallorum, Mercurio Philosophorum, Azotho, et Lapide seu Tinctura Physicorum Conficienda è RERUM Natura, Experientia, et Autorum Præstantium fide Studio \& labore Andreæ Libavii M.D.P. et Physici Rotemburgici Depromti \& Expositi, more Veteris Philosophiæ cum Perspicuitate Euidente. In Treatise vi, Tractatus de iudicio aquarum mineralium in tres libros distributus, Part II; Frankfurt, Germany, 1597.

13. Buser, H.J.; Schwarzenbach, D.; Fetter, W.; Ludi, A. The Crystal Structure of Prussian Blue: $\mathrm{Fe}_{4}\left[\mathrm{Fe}(\mathrm{CN})_{6}\right]_{3} \cdot x \mathrm{H}_{2} \mathrm{O}$. Inorg. Chem. 1977, 16, 2704-2710. [CrossRef]

14. Coleby, L.J.M. A history of Prussian blue. Ann. Sci. 1939, 4, 206-211. [CrossRef]

15. Kraft, A. On the discovery and history of Prussian blue. Bull. Hist. Chem. 2008, 33, 61-67. Available online: http://acshist.scs.illinois.edu/bulletin_open_access/v33-2/v33-2\%20p61-67.pdf (accessed on 4 August 2019).

16. Kraft, A. "Notitia Cœrulei Berolinensis Nuper Inventi" on the 300th anniversary of the first publication on Prussian blue. Bull. Hist. Chem. 2011, 36, 3-9. Available online: http://acshist.scs.illinois.edu/bulletin_open _access/v33-2/v33-2\%20p61-67.pdf (accessed on 4 August 2019).

17. Woodward, J. Praeparatio caerulei Prussiaci ex Germaniâ. Philos. Trans. 1724, 33, 15-17. [CrossRef]

18. Brown, J. Observations and experiments upon the foregoing preparation. Philos. Trans. 1724, 33, 17-24. [CrossRef]

19. Sur le Bleue de Prusse. Hist. Acad. R. Sci. Mém. Math. Phys. 1725, 44-51. Available online: https://books. google.ch/books?id=YKgSAAAAYAAJ\&lpg=PA44\&ots=TbWGUkGQJO\&dq=Nouvelles\%20observation s\%20sur\%20la\%20pr\%C3\%A9paration\%20du\%20Bleu $\% 20 \mathrm{de} \% 20$ Prusse\&pg=PA44\#v=onepage\&q=No uvelles $\% 20$ observations $\% 20$ sur $\% 201 \mathrm{la} \% 20 \mathrm{pr} \% \mathrm{C} 3 \%$ A9paration $\% 20 \mathrm{du} \% 20 \mathrm{Bleu} \% 20 \mathrm{de} \% 20 \mathrm{Prusse} \& \mathrm{f}=$ false (accessed on 4 August 2019).

20. l'Aine, G. Observations sur la préparation du Bleu de Prusse, ou de Berlin. Hist. Acad. R. Sci. Mém. Math. Phys. 1725, 153-172. Available online: https://books.google.ch/books?id=TP_RqzAwoUwC\&lpg=PA312\&ot s=DjK9ing-1L\&dq=Observations $\% 20$ sur $\% 201 \mathrm{a} \% 20 \mathrm{pr} \% \mathrm{C3} \%$ A9paration $\% 20 \mathrm{du} \% 20 \mathrm{Bleu} \% 20 \mathrm{de} \% 20$ Prusse \&pg=PA312\#v=onepage\&q=Observations $\% 20$ sur\%20la\%20pr\%C3\%A9paration $\% 20 \mathrm{du} \% 20 \mathrm{Bleu} \% 20 \mathrm{de} \%$ 20Prusse\&f=false (accessed on 4 August 2019).

21. l'Aine, G. Nouvelles observations sur la préparation du Bleu de Prusse. Hist. Acad. R. Sci. Mém. Math. Phys. 1725, 220-237.

22. Chadwick, B.M.; Sharpe, A.G. Transition Metal Cyanides and Their Complexes. Adv. Inorg. Chem. Radiochem. 1966, 8, 83-176. [CrossRef]

23. Sharpe, A.G. The Chemistry of Cyano Complexes of the Transition Metals; Academic Press: New York, NY, USA, 1976; pp. 99-126.

24. L.E.L. Ethel Churchill, or, The Two Brides; H. Colburn: London, UK, 1837; Volume 3.

25. Scheele, C.W. Försök, beträffande det färgande ämnet uti Berlinerblå. Kongl. Vetenskaps Academiens 1782, 3, 264-275.

26. Miller, L. LEL: The Lost Life and Scandalous Death of Letitia Elizabeth Landon, the Celebrated "Female Byron"; Knopf Doubleday: New York, NY, USA, 2019.

27. Lewis, W. Commercium Philisophico-Technicum, or, the Philosophical Commerce of Arts: Designed as an Attempt to Improve Arts, Trades, and Manufactures; H. Baldwin: London, UK, 1763.

28. Buchan, W. Domestic Medicine: or, a Treatise on the Prevention and Cure of Diseases by Regimen and SIMPLE Medicines. with an Appendix, Containing a Dispensatory for the Use of Private Practitioners, 11th ed.; Strahan and Cadell: London, UK, 1790.

29. Royal College of Surgeons. A Draught for the Reformation of the London Pharmacopoeia, Prepared for the Perusal of the Members of the College of Physicians, by their Committee Appointed to that Purpose; Royal College of Surgeons: London, UK, 1742.

30. Lewis, W. Pharmacopoeia reformata, or, an Essay for a Reformation of the London Pharmacopoeia, by a Set of Remarks on the Draught for a New One, and on The Brief Account of the Proceedings of the Committee appointed by the College of Physicians to thoroughly reform Their Book. Interspersed with Some Occasional Observations On some of the Most Celebrated Modern Dispensatories and the Present State of Pharmacy; R. Willock: London, UK, 1744. 
31. Duncan, A. The Edinburgh New Dispensatory: Containing I. the Elements of Pharmaceutical Chemistry. II. The Materia Medica; or the Natural, Pharmaceutical and Medical History of the Different Substances Employed IN Medicine. III. The Pharmaceutical Preparations and Compositions. Including Complete and Accurate Translations of the Octavo Edition of the London Pharmacopoeia published in 1791; Dublin Pharmacopoeia, published in 1794; and of the New Edition of the Edinburgh Pharmacopoeia, published in 1803; Bell and Bradfute: Edinburgh, UK, 1804.

32. Powell, R. The Pharmacopoeia of The Royal College of Physicians of London M.DCCC.IX. Translated into English with Notes, 2nd ed.; Longman, Hurst, Rees, and Orme: London, UK, 1809.

33. Crosland, M.P. Historical Studies in the Language of Chemistry, 2nd ed.; Dover: New York, NY, USA, 1978.

34. Thorpe, E. (Ed.) The Scientific Papers of the Honourable Henry Cavendish, FRS.; Cambridge University Press: Cambridge, UK, 1921; Volume 2, p. 326.

35. Macquer, P.J. Elémens de Chymie Théorique; Jean-Thomas Herissant: Paris, France, 1749.

36. Macquer, P.J. Elémens de Chymie-Pratique; Jean-Thomas Herissant: Paris, France, 1751.

37. Macquer, P.J. Dictionnaire de Chymie Contenant la Théorie et la Pratique de Cette Science, Son Application à la Physique, à l'histoire Naturelle, à la Médecine E aux Arts dépendans de la Chymie; P.Fr. Didot jeune: Paris, France, 1766.

38. Baume, A. Chymie Expérimentale et Raisonée; P.Fr. Didot le jeune: Paris, France, 1773.

39. Bergman, T. Physical and Chemical Essays Translated from the Original Latin of sir Torbern Bergman Knight of the Order of Wasa, Professor of Chemistry at Upsal, EC. EC. EC. by Edmund Cullen; J. Murray, London, UK: Balfour and Co, W. Dickson and J. Dickson, Edinburgh, UK: L. White, Dublin, Ireland, 1784; Volumes 1 and 2.

40. Bergman, T. Physical and Chemical Essays translated from the original Latin of Sir Torbern Bergman Knight of the Order of Wasa, Professor of chemistry at Upsal, Ec. Ec. Ec.; 1784, G. Mudie and J. and J. Fairbairn: Edinburgh, UK, 1791; Volume 3.

41. De Morveau, G. Memoire sur les Dénominations Chymiques, la nécessité d'en perfectionner le Systéme, \& les régles pour y parvenir. Obs. Phys. Chim. Hist. Nat. Arts 1782, 19, 370-383.

42. Ohrström, L.; Reedijk, J. Names and symbols of the elements with atomic numbers 113, 115, 117 and 118 (IUPAC Recommendations 2016). Pure Appl. Chem. 2016, 88, 1225-1229. [CrossRef]

43. De Morveau, L.; de Fourcroy, B. MÉTHODE DE NOMENCLATURE CHIMIQUE. Proposé par MM. DE MORVEAU, LAVOISIER, BERTHOLET, E DE FOURCROY. ON Y A JOINT Un nouveau Système de Caractères Chimiques, adaptés à cette Nomenclature, par MM. HASSENFRATZ \& ADET; Cuchet: Paris, France, 1787.

44. De Morveau, L.B.B.G.; ADET, P.A.; Berthollet, C.L.; de FOURCROY, A.F.; HASSENFRATZ, J.H.; Lavoisier, A.L.; SAINT JOHN, J. METHOD OF CHYMICAL NOMENCLATURE PROPOSED BY MESSRS. DE MORVEAU, LAVOISIER, BERTHOLET, AND DE FOURCROY. TO WHICH IS ADDED A NEW SYSTEM OF CHYMICAL CHARACTERS, ADAPTED TO THE NOMENCLATURE, by MesS. HASSENFRATZ and ADET. TRANSLATED FROM THE FRENCH, AND THE NEW CHEMICAL NAMES ADAPTED TO THE GENIUS OF THE ENGLISH LANGUAGE; G. Kearsley: London, UK, 1788.

45. Conant, J.B. The Overthrow of Phlogiston Theory: The Chemical Revolution of 1775-1789; Harvard University Press: Cambridge, USA, 1950.

46. White, J.H. The History of the Phlogiston Theory; AMS Press Inc.: New York, NY, USA, 1973.

47. De la, M. Essai sur la nomenclature chimique. Obs. Phys. Chim. Hist. Nat. Arts 1787, 31, 270-285.

48. Keir, J. The First Part of a Dictionary of Chemistry, Ec. By J.K: and S.A.Sc.; Pearson and Rollason: Birmingham, UK, 1789.

49. Dickson, S. An Essay on Chemical Nomenclature, by Stephen Dickson, M.D. State Physician in Ireland; Professor of the Practice of Medicine in Trinity College, Dublin; Vice President of the College of Physicians; Secretary to the Committee of Science of the R.I.A; F.R.S.S.A. and of Different Medical Societies in London, Edinburgh, Dublin, Ec. in which are Comprised Observations on the Same Subject, by Richard Kirwan, LL. D.F.R.S.M.R.I.A and of the Academies of Stockholm, Upsal, Berlin, Manchester, Philadelphia, Ec; J. Johnson: Dublin, Ireland, 1796.

50. Berzelius, J.J. Essai sur la nomenclature chimique. J. Phys. Chim. Hist. Nat. Arts 1811, 73, 253-286.

51. Tassaert. Analyse du cobalt de Tunaberg suivre de plusleurs moyens d'obtenir ce metal d l'état de pureté, et de quelques-unes de ses propriétés les plus remarquables. Ann. Chim. Phys. 1798, 28, 92-107.

52. Partington, J.R. A History of Chemistry; MacMillan: London, UK, 1964; Volume 4, p. 920.

53. Klaproth, M.H. Mémoires de Chimie Contenant des Analyses de Minéraux, 2 Volumes; Buisson: Paris, France, 1807.

54. Gmelin, L. Ueber Kobaltsäure. J. Chem. Phys. 1822, 6, 235-237. Available online: https://ia800709.us.archive.org/BookReader/BookReaderImages.php?zip=/26/items/journalfrchemie3 
4unkngoog/journalfrchemie34unkngoog_tif.zip\&file=journalfrchemie34unkngoog_tif/journalfrchemie34u nkngoog_0249.tif\&scale $=4 \&$ rotate $=0$ (accessed on 4 August 2019).

55. Dingler, E.M. Ein Beitrag zur Kenntniss einiger elektronegativen Metalle. Archiv. Ges. Naturlehre 1829, 18, 249-252.

56. Winkelblech, C. Ueber die Cobaltoxyde. Ann. Pharm. 1835, 13, 148-168. [CrossRef]

57. Beetz, W. Ueber die Oxyde des Kobalts und einige Verbindungen der selben. Ann. Phys. Chem. 1844, 137, 472-506. [CrossRef]

58. Rammelsberg, C. Ueber die Verbindungen der Jodmetalle mit Ammoniak. Ann. Phys. Chem. 1839, 124, 151-185. [CrossRef]

59. Rammelsberg, C. Beiträge zur Kenntniss der Jodsauren und Überjodsauren Salze. Ann. Phys. Chem. 1838, 120, 545-591. [CrossRef]

60. West, J.B. Joseph Black, carbon dioxide, latent heat, and the beginnings of the discovery of the respiratory gases. Am. J. Physiol. Lung Cell. Mol. Physiol. 2014, 306, L1057-L1063. [CrossRef] [PubMed]

61. Fischer, N.W. Ueber die salpetrichtsauren Salze. Ann. Phys. Chem. 1848, 150, 115-125. [CrossRef]

62. Erdmann, O.L. Ueber einige salpetrigsaure Nickel- und Kobalt-verbindungen. J. Prakt. Chem. 1866, 97, 385-413. Available online: https://reader.digitale-sammlungen.de/de/fs1/object/display/bsb10072520_00403. html? contextType=scan\&contextSort $=$ score $\% 2$ Cdescending \&contextRows $=10 \&$ context=einige + salpetrig saure (accessed on 4 August 2019). [CrossRef]

63. Yoshimichi, K. Structures of the Erdmann's salt, $\mathrm{NH}_{4}\left[\mathrm{Co}\left(\mathrm{NH}_{3}\right)_{2}\left(\mathrm{NO}_{2}\right)_{4}\right]$ and some other related nitro-ammine-cobalt (III) complexes. Bull. Chem. Soc. Jpn. 1957, 30, 13-21. [CrossRef]

64. Vauqelin, N.L. Mémoire sur le Palladium et le Rhodium. Ann. Chim. 1813, 88, 167-186.

65. Cleve, P.T. Om någar märkliga isomerier uti den oorganiska kemien, Oefversigt. Akad. Förh. 1871, $28,175-179$.

66. Peyrone, M. Ueber die Einwirkung des Ammoniaks auf Platinchlorür. Ann. Chem. Pharm. 1844, 51, 1-29. [CrossRef]

67. Zeise, W.C. Von der Wirkung zwischen Platinchlorid und Alkohol, und von den dabei entstehenden neuen Substanzen. Mag. Pharm. 1831, 35, 105-111. [CrossRef]

68. Zeise, W.C. Von der Wirkung zwischen Platinchlorid und Alkohol, und von den dabei entstehenden neuen Substanzen. Ann. Phys. Chem. 1831, 97, 497-541. [CrossRef]

69. Zeise, W.C. De chlorido platinae et acohole vini sese invicem permutantibus nec non de novis substantiis inde oriundis. In Anniversary Volume of the University of Copenhagen; 1830.

70. Gmelin, H.L. Ueber ein besonderes Cyaneisenkalium, und über eine neue Reihe von blausauren Eisensalzen. J. Chem. Phys. 1822, 34, 325-346. Available online: https://books.google.ch/books?id=_-Q4AAAAMAAJ\&lp $\mathrm{g}=$ PP12\&ots=HozIznAfo7\&dq=Ueber\%20ein \%20besonderes $\% 20$ Cyaneisenkalium $\% 2 \mathrm{C} \% 20$ und $\% 20 \% \mathrm{C} 3$ \%BCber\%20eine \%20neue $\% 20$ Reihe $\% 20$ von $\% 20$ blausauren $\% 20$ Eisensalzen.\&pg=PA325\#v=onepage\&q= Ueber\%20ein\%20besonderes\%20Cyaneisenkalium,\%20und\%20\%C3\%BCber\%20eine\%20neue\%20Reihe\% 20von\%20blausauren\%20Eisensalzen.\&f=false (accessed on 4 August 2019).

71. Reinecke, A. Über Rhodanchromammonium-Verbindungen. Ann. Chem. Pharm. 1863, 126, 113-118. [CrossRef]

72. Nassar, M.W.I.; Attia, K.A.S.M.; Mohamad, A.A.A.; Said, R.A.M.; Gaber, R.F.A. Atomic absorption spectrometric determination of metoclopramide hydrochloride using ammonium reineckate. World J. Pharm. Res. 2018, 7, 1-12. [CrossRef]

73. Gros, J. Ueber eine neue Klasse von Platinsalzen. Ann. Pharm. 1838, 36, 241-256. [CrossRef]

74. Gerhardt, C. Recherches sur les combinaisons ammoniacales du platine. C. R. 1850, 31, 241-244. Available online: https://www.biodiversitylibrary.org/item/16573\#page/251/mode/1up (accessed on 4 August 2019).

75. Hadow, E.A. The Platinum-bases: The best mode of obtaining and identifying them; some new Compounds. J. Chem. Soc. 1866, 19, 345-352. [CrossRef]

76. Vortmann, G. Beiträge zur Kenntniss der Kobaltammoniumverbindungen. Monatsh. Chem. 1885, 6, 404-445. [CrossRef]

77. Tschugajeff, L.; Skanawy-Grigorjewa, M.; Posnjak, A. Über Die Hydrazin-Carbylamin-Komplexe des Platins. Z. Anorg. Allg. Chem. 1925, 148, 37-42. [CrossRef]

78. Magnus, G. Ueber einige Verbindungen des Platinchlorürs. Ann. Phys. Chem. 1828, 14, 239-242. [CrossRef]

79. Jörgensen, S.M.; Sörensen, S.P.L. Ueber eine neue, mit Magnus' grünem Sake isomere, rote Verbindung. Z. Anorg. Allg. Chem. 1905, 48, 441-445. [CrossRef] 
80. Buckton, G.B. On the Platino-tersulphocyanides and the Platino-bisulpho- cyanides, two new series of salts, and their decompositions. Q. J. Chem. Soc. 1855, 7, 22-43. [CrossRef]

81. Thomson, T. On some of the compounds of chromium. Phil. Trans. 1827, 117, 159-230. Available online: https://www.jstor.org/stable/107874 (accessed on 4 August 2019). [CrossRef]

82. Cleve, P.T. Om platinabasernas constitution. Nova Acta Reg. Soc. Sci. Upsal. 1866, 6, 112-118.

83. Reiset, J. Observations sur une combinaison nouvelle de chlorure de platine et d'ammoniaque, considérée comme le radical des sels de Gros. C. R. 1840, 10, 870-872. Available online: https://www.biodiversitylibrary. org/item/112146\#page/873/mode/1up (accessed on 5 August 2019).

84. Reiset, J. Mémoire sur les combinaisons de deux nouvelles bases alcalines contenant du platine. Ann. Chim. 1844, 11, 417-433.

85. Reiset, J. Mémoire sur les combinaisons de deux nouvelles bases alcalines contenant du platine. C. R. 1844, 18, 1100-1105. Available online: https://www.biodiversitylibrary.org/item/21168\#page/1115/mode/1up (accessed on 5 August 2019).

86. Cossa, A. Sopra alcuni derivati di una nuova base ammoniacale del platino. Atti R. Accad. dei Lincei, Rendiconti 1891, 7, 3-4. Available online: https://www.biodiversitylibrary.org/item/155653\#page/9/mode/1up (accessed on 5 August 2019).

87. Cossa, A. Sopra un nuovo isomero de sale verde de Magnus. Gazz. Chim. Ital. 1890, 20, 725-753.

88. Barker, G.F. Frederick Augustus Genth. Proc. Am. Philos. Soc. 1901, 40, x-xxii. Available online: https://www.biodiversitylibrary.org/item/31072\#page/204/mode/1up (accessed on 5 August 2019).

89. Genth, F.A. Vorlaufige Notiz über Gepaarte Kobalt-Verbindungen. Keller-Tiedem's Nordamerikanischer Monatsbericht für Natur- und Heilkunde 1851, 2, 8-12.

90. Claudet, F. On a class of ammoniacal compounds of cobalt. Philos. Mag. 1851, 2, 253-260. [CrossRef]

91. Claudet, F. Sur une classe de composés ammoniacaux du cobalt. Ann. Chim. Phys. 1851, 33, 483-493. Available online: https:/gallica.bnf.fr/ark:/12148/cb343780820/date.r=Annales+de+chimie+et+de+physique.langEN (accessed on 5 August 2019).

92. Fremy, E. Recherches sur le cobalt. C. R. 1851, 32, 509-510. Available online: https://www.biodiversitylibrary. org/item/16567\#page/511/mode/1up (accessed on 5 August 2019).

93. Fremy, E. Recherches sur le cobalt. C. R. 1851, 32, 808-810. Available online: https://www.biodiversitylibrary. org/item/16567\#page/818/mode/1up (accessed on 5 August 2019).

94. Fremy, E. Note sur les sels ammoniaco-cobaltiques suroxygénés. Ann. Chim. Phys. 1852, 34, 90-91. Available online: https://gallica.bnf.fr/ark:/12148/cb343780820/date.r=Annales+de+chimie+et+de+physique.langEN (accessed on 5 August 2019).

95. Fremy, E. Recherches sur le cobalt. Ann. Chim. Phys. 1852, 35, 257-311. Available online: https: //gallica.bnf.fr/ark:/12148/cb343780820/date.r=Annales+de+chimie+et+de+physique.langEN (accessed on 5 August 2019).

96. Gibbs, W.; Genth, F.A. Researches on the ammonia-cobalt bases. Am. J. Sci. 1857, 23, 234-265. Available online: https://archive.org/details/mobot31753002152509/page/234 (accessed on 5 August 2019).

97. Gibbs, W.; Genth, F.A. Researches on the ammonia-cobalt bases. Am. J. Sci. 1857, 23, 319-341. Available online: https://archive.org/details/mobot31753002152509/page/318 (accessed on 5 August 2019).

98. Gibbs, W.; Genth, F.A. Researches on the ammonia-cobalt bases. Am. J. Sci. 1857, 24, 86-107. Available online: https://archive.org/details/mobot31753002152517/page/78 (accessed on 5 August 2019).

99. Gibbs, W. Researches on the hexatomic compounds of cobalt. Proc. Am. Acad. Arts Sci. 1875, 10, 1-38. Available online: https://www.biodiversitylibrary.org/item/22173\#page/9/mode/1up (accessed on 5 August 2019). [CrossRef]

100. Gibbs, W. Researches on the hexatomic compounds of cobalt. Am. J. Sci. 1873, 6, 116-126. Available online: https://archive.org/details/mobot31753002152848/page/116 (accessed on 5 August 2019). [CrossRef]

101. Gibbs, W. Researches on the hexatomic compounds of cobalt. Proc. Am. Acad. Arts Sci. 1875, 11, 1-51. Available online: https://www.archive.org/download/proceedingsofam11amer/page/n8_w347 (accessed on 5 August 2019). [CrossRef]

102. Jörgensen, S.M. Beitrage zur Chemie der Kobaltammoniak-verbindungen. J. Prakt. Chem. 1879, 19, 49-69. [CrossRef]

103. Jörgensen, S.M. Beitrage zur Chemie der Kobaltammoniak-verbindungen. J. Prakt. Chem. 1879, 19, $209-247$. [CrossRef] 
104. Jörgensen, S.M. Zur Constitution der Kobalt-, Chrom- und Rhodiumbasen II. J. Prakt. Chem. 1890, 42, $206-221$. [CrossRef]

105. Jörgensen, S.M. Ueber saure Luteo- und Roseonitrate, Ueber saure Luteo- und Roseonitrate. J. Prakt. Chem. 1891, 44, 63-66. [CrossRef]

106. Jörgensen, S.M. Beiträge zur Chemie der Rhodiumammoniakverbindungen. Part VI Ueber Roseorhodiumsalze. J. Prakt. Chem. 1886, 34, 394-406. [CrossRef]

107. Jörgensen, S.M. Zur Konstitution der Kobalt-, Chrom- und Rhodiumbasen XI. Z. Anorg. Chem. 1899, 19, 109-157. [CrossRef]

108. Werner, A. Ueber stereoisomere Kobaltverbindungen. Ber. Dtsch. Chem. Ges. 1901, 34, 1705-1719. [CrossRef]

109. Blau, F. Über neue organische Metallverbindungen. Ein Beitrag zur Kenntniss der Metalliake. Monatsh. Chem. 1893, 3, 647-689. [CrossRef]

110. Weltzien, C. Ueber die Ammoniummoleküle der Metalle. Justus Liebigs Ann. Chem. 1856, 97, 19-33. Available online: https://onlinelibrary.wiley.com/doi/pdf/10.1002/jlac.18560970105 (accessed on 4 August 2019). [CrossRef]

111. Weltzien, C. Noch ein Wort über die Ammoniummoleküle der Metalle. Justus Liebigs Ann. Chem. 1856, 97, 108-110. [CrossRef]

112. Weltzien, C. Ueber die ammoniakalischen Kobaltbasen. Justus Liebigs Ann. Chem. 1862, 121, $247-250$. [CrossRef]

113. Werner, A. Die Ammoniumsalze als einfachste Metallammoniake. Ber. Dtsch. Chem. Ges. 1903, 36, 147-159. [CrossRef]

114. Hidakas, J.; Yamada, H.; Tsuchi, R. Rotatory Dispersion of Metallic Co-ordination Compounds. I. Rotatory Dispersion in the First and the Second Absorption Bands of Cobaltic Compounds 1. Bull. Chem. Soc. Jpn. 1958, 31, 921-925. [CrossRef]

115. Hirotaro, K. Physicochemical studies on cobalt salts of higher fatty acids. IX. Cobalt complex soap. Bull. Chem. Soc. Jpn. 1962, 35, 388-930. [CrossRef]

116. Lepadatu, C.I. On electronic spectra of praseosalts. Rev. Roum. Chim. 1966, 11, 489-495.

117. Hara, R. Application of high-frequency chemical analysis to the studies of metallic complex salts. V. Reaction of some ammine complex salts of cobalt and chromium with protein. Yakugaku Zasshi 1951, 71, 1144-1152. [CrossRef]

118. Mohamud, S.; Pagola, S. Revisiting the crystal structure of $\left[\mathrm{Co}\left(\mathrm{NH}_{3}\right)_{5} \mathrm{Cl}\right] \mathrm{Cl}_{2}$ using synchrotron powder diffraction: to what extent single-crystal diffraction from 1960s got it right? Powder Diffr. 2017, 32, 179-186. [CrossRef]

119. Odling, W., Translator; A Notation, classification and nomenclature by Auguste Laurent; Harrison and Sons: London, UK, 1855.

120. Ramberg, P.J. Chemical Structure and Spatial Arrangement: The Early History of Stereochemistry 1874-1914; Ashgate: Aldershot, UK, 2003.

121. Palmer, W.G. A History of the Concept of Valency to 1930; Cambridge University Press: Cambridge, UK, 1965.

122. IUPAC Gold Book. Available online: https://goldbook.iupac.org/terms/view/V06588 (accessed on 24 July 2019).

123. Towards a Comprehensive Definition of Valence. Available online: https://iupac.org/projects/project-details /?project_nr=2018-030-2-200 (accessed on 5 August 2019).

124. Kekulé, A. Über die sogenannten gepaarten Verbindungen und die Theorie der mehratomigen Radicale. Ann. Chem. Pharm. 1857, 104, 129-150. [CrossRef]

125. Russell, C.A. The History of Valence; Humanities Press: New York, USA, 1971.

126. Meyer, V. Zur Valenz und Verbindungsfähigkeit des Kohlenstoffs. Justus Liebigs Ann. Chem. 1876, 180, 192-206. [CrossRef]

127. Frankland, E. On a New Series of Organic Bodies containing Metals. Philos. Trans. 1852, 142, 417-444. [CrossRef]

128. Wichelhaus, H. Ueber die Verbindungen des Phosphors. Ann. Chem. Pharm. 1868, (Suppl. 6), $257-280$.

129. Von Hofmann, A.W. Introduction to Modern Chemistry, Experimental and Theoretic, Embodying Twelve Lectures Delivered in the Royal College of Chemistry, London; Walton and Maberley: London, UK, 1865. 
130. Gay-Lussac, T. Extrait de plusieurs notes sur les métaux de la potasse et de la soude, lues à l'Institut depuis le 12 janvier jusqu'au 16 mai. Gazette Nationale, ou le Moniteur Universel 1808, 40, 581-582. Available online: https://gallica.bnf.fr/ark:/12148/cb34452336z/date.item (accessed on 5 August 2019).

131. Davy, H. The Bakerian Lecture. An account of some new analytical researches on the nature of certain bodies, particularly the alkalies, phosphorus, sulphur, carbonaceous matter, and the acids hitherto undecomposed; with some general observations on chemical theory. Philos. Trans. 1809, 99, 39-104.

132. Kekulé, A. Ueber die Constitution und die Metamorphosen der chemischen Verbindungen und über die chemische Natur des Kohlenstoffs. Ann. Chem. Pharm. 1858, 106, 129-159. [CrossRef]

133. Kekulé, A. Sur l'atomicité des éléments. C. R. 1864, 58, 510-514. Available online: https://www.biodiversityli brary.org/item/23663\#page/518/mode/1up (accessed on 5 August 2019).

134. Madan, H.G. Remarks on some Points in the Nomenclature of Salts. J. Chem. Soc. 1870, 23, 22-28. [CrossRef]

135. Williamson. Remarks on chemical nomenclature and notation. J. Chem. Soc. 1864, 17, 421-432. [CrossRef]

136. Connelly, N.G.; Damhus, T.; Hartshorn, R.M.; Hutton, A.T. Nomenclature of Inorganic Chemistry. IUPAC Recommendations 2005. Issued by the Division of Chemical Nomenclature and Structure Representation in collaboration with the Division of Inorganic Chemistry; Rule IR-3.3.2; RSC Publishing: Cambridge, UK, 2005.

137. Favre, H.A.; Powell, W.H. Nomenclature of Organic Chemistry-IUPAC Recommendations and Preferred Names 2013; Royal Society of Chemistry: Cambridge, UK, 2013.

138. Kragh, K.S.M. Jørgensen and his controversy with A. Werner: A reconsideration. Br. J. Hist. Sci. 1997, 30, 203-219. Available online: https://www.jstor.org/stable/4027717 (accessed on 4 August 2019). [CrossRef]

139. Kauffman, G.B. Sophus Mads Jørgensen and the Werner-Jørgensen Controversy. Chymia 1960, 6, $180-204$. Available online: https://www.jstor.org/stable/27757198 (accessed on 4 August 2019). [CrossRef]

140. Kauffman, G.B. Sophus Mads Jorgensen (1837-1914): A chapter in coordination chemistry history. J. Chem. Educ. 1959, 36, 521-527. [CrossRef]

141. Whisnant, D.M. Bonding theory/The Werner-Jorgensen controversy. J. Chem. Educ. 1993, 70, 902. [CrossRef]

142. Gerhardt, C. Sur la constitution des Sels organiques à Acides complexes, et leurs Rapports avec les Sels ammoniacaux. Annales de Chimie et de Physique 1839, 72, 184-214. Available online: https://gallica.bnf.fr/ark: /12148/cb343780820/date1839 (accessed on 5 August 2019).

143. Berzelius, J. Ansichten in Betreff der organischen Zusammensetzung. Ann. Phys. Chem. 1846, 78, 161-188. [CrossRef]

144. Hare, R. Objections to the nomenclature of the celebrated Berzelius: With suggestions respecting a substitute, in a letter to Professor Silliman: first published in 1834, and republished in Silliman's Journal for 1835, Vol. XXVII. Silliman's J. 1835, 27, 1-23. Available online: https://archive.org/details/101125880.nlm.nih.gov (accessed on 4 August 2019).

145. Berzelius, J.J. Jahres-Bericht über die Fortschritte der Chemie und Mineralogie; Laupp'sche Buchhandlung: Tübingen, Germany, 1842; Volume 21.

146. Blomstrand, C.W. Die Chemie der Jetztzeit vom Standpunkte der electrochemischen Auffassung. Aus Berzellius lehre entwickelt; Carl Winter's Universitätsbuchhandlung: Heidelberg, Germany, 1869.

147. Jörgensen, S.M. Ueber das Verhältniss zwischen Luteo- und Roseosalzen. J. Prakt. Chem. 1884, $29,409-422$. [CrossRef]

148. Jörgensen, S.M. Zur Constitution der Kobaltbasen I. J. Prakt. Chem. 1890, 41, 429-439. [CrossRef]

149. Werner, A. Beitrag zur Konstution anorganische Verbindungen. Z. Anorg. Chem. 1893, 3, 267-330. [CrossRef]

150. Jörgensen, S.M. Zur Konstitution der Kobalt-, Chrom- und Rhodiumbasen V. Z. Anorg. Chem. 1894, 5, 147-196. [CrossRef]

151. Jörgensen, S.M. Zur Konstitution der Kobalt-, Chrom- und Rhodiumbasen VI. Z. Anorg. Chem. 1894, 7, 289-330. [CrossRef]

152. Hantzsch, A.; Werner, A. Ueber räumliche Anordnung der Atome in stickstoffhaltigen Molekülen. Ber. Dtsch. Chem. Ges. 1890, 23, 11-30. [CrossRef]

153. Hantzsch, A.; Werner, A. Bemerkungen über stereochemisch isomere Stickstoffverbindungen. Ber. Dtsch. Chem. Ges. 1890, 23, 1243-1253. [CrossRef]

154. Hantzsch, A.; Werner, A. Bemerkungen über stereochemisch isomere Stickstoffverbindungen. Ber. Dtsch. Chem. Ges. 1890, 23, 2764-2769. [CrossRef]

155. Werner, A. Beiträge zur Theorie der Affinität und Valenz. Vierteljahresschr. Naturforsch. Ges. Zürich 1891, 36, 129-161. Available online: https://www.ngzh.ch/archiv/1891_36/36_2/36_10.pdf (accessed on 4 August 2019). 
156. Werner, A.; Miolati, A. Beiträge zur Konstitution anorganischer Verbindungen. Z. Phys. Chem. 1893, 12, 35-55. [CrossRef]

157. Werner, A. Beitrag zur Konstitution anorganischer Verbindungen. V. Mitteilung. Die Kobaltammoniakverbindungen und ihre Nomenklatur. Z. Anorg. Chem. 1897, 14, 23-27. [CrossRef]

158. Werner, A. Neuere Anschauungen auf dem Gebiete der Anorganischen Chemie, 4th ed.; Friedr Vieweg \& Sohn: Braunschweig, Germany, 1920.

159. Hedley, E.P., Translator; New Ideas in Inorganic Chemistry by Dr A. Werner. Translated with the Author's Sanction, from the Second German Edition; Longmans, Green and Co.: London, UK, 1911.

160. Fernelius, W.C. The Nomenclature of Coordination Compounds from Pre-Werner Times to the 1966 IUPAC Report. ACS Ser. 1967, 62, 147-160.

161. Bailar, J.C., Jr. The chemistry of the coordination compounds; ACS Monograph Series; Reinhold Publishing Corporation: New York, NY, USA; Chapman and Hall: London, UK, 1956.

162. Nomenclature of Inorganic Chemistry. Definitive Rules 1970, 2nd ed.; Butterworths: London, UK, 1971; p. 39.

163. Leigh, G.J. (Ed.) Nomenclature of Inorganic Chemistry. Recommendations Rules 1990; Rule I-10.2.6; Blackwell: Oxford, UK, 1990.

164. Connelly, N.G.; Damhus, T.; Hartshorn, R.M.; Hutton, A.T. Nomenclature of Inorganic Chemistry. IUPAC Recommendations 2005. Issued by the Division of Chemical Nomenclature and Structure Representation in Collaboration with the Division of Inorganic Chemistry; Rule IR-9.1.2.7; RSC Publishing: Cambridge, UK, 2005.

165. Ihde, A.J. The Karlsruhe Congress: A Centennial Retrospect. J. Chem. Educ. 1961, 38, 83-86. [CrossRef]

166. Hudson, J. The History of Chemistry; Palgrave: London, UK, 1992; pp. 122-137.

167. De Milt, C. The Congress at Karlsruhe. J. Chem. Educ. 1951, 28, 421-425. [CrossRef]

168. Ball, P. $\mathrm{H}_{2} \mathrm{O}:$ A Biography of Water; Weidenfeld and Nicolson: London, UK, 1999.

169. Higgins, W. A Comparative View of the Phlogistic and Antiphlogistic Theories. With Inductions. To Which is Annexed, an Analysis of the Human Calculus, By William Higgins, of Pembroke College, Oxford; J. Murray: London, $\mathrm{UK}, 1789$.

170. Higgins, W. A Comparative View of the Phlogistic and Antiphlogistic Theories. With Inductions. To Which is Annexed, an Analysis of the Human Calculus, By William Higgins, of Pembroke College, Oxford, 2nd ed.; J. Murray: London, UK, 1791.

171. Dalton, J. A New System of Chemical Philosophy. Part I; R. Bickerstaff: London, UK, 1808.

172. Dalton, J. A New System of Chemical Philosophy. Part II; R. Bickerstaff: London, UK, 1810.

173. Grotthuss, C.J.T. Sur la décomposition de l'eau et des corps qu'elle tient endissolution à l'aide de l'électricité galvanique. Ann. Chim. 1806, 58, 54-74.

174. Grotthuss, C.J.T. De l'influence de l'électricité galvanique sur les végétations métalliques. Ann. Chim. 1807, 63, 5-34.

175. Kekulé, A. Lehrbuch der organischen Chemie oder der Chemie der Kohlenstoffverbindungen; Ferdinand Enke: Erlangen, Germany, 1861; Volume 1.

176. Kekulé, A. Lehrbuch der organischen Chemie oder der Chemie der Kohlenstoffoerbindungen; Ferdinand Enke: Erlangen, Germany, 1866; Volume 2.

177. Kekulé, A. Lehrbuch der organischen Chemie oder der Chemie der Kohlenstoffoerbindungen; Ferdinand Enke: Erlangen, Germany, 1867; Volume 3.

178. Meyer, L. Die Modernen Theorien der Chemie und ihre Bedeutung für die chemische Statik; Maruschke \& Barendt: Breslau, Germany, 1864.

179. Beilstein, F. Handbuch der Organischen Chemie. 1. Abtheilung. Einleitung. Specieller Theil: Fettreihe; Von Leopold Voss: Hamburg and Leipzig, Germany, 1881.

180. Beilstein, F. Handbuch der Organischen Chemie. 2. Specieller Theil: Aromatische Reihe; Von Leopold Voss: Hamburg/Leipzig, Germany, 1883.

181. Baskerville, C. International Congresses. Science 1910, 32, 652-659. [CrossRef]

182. Congrès de nomenclature chimique (Genève, 1892). Bull. Soc. Chim. Fr. 1892, 3, XIII-XXIV.

183. Brock, W.H.; Jensen, K.A.; Jørgensen, C.K.; Kauffman, G.B. The origin and dissemination of the term "ligand" in chemistry. Polyhedron 1983, 2, 1-7. [CrossRef]

184. Stock, A. Siliciumchemie und Kohlenstoffchemie. Ber. Dtsch. Chem. Ges. 1917, 50, 170-182. [CrossRef]

185. Klement, R. Phosphorsäure als Ligand in komplexen Kobaltverbindungen. Z. Anorg. Allgem. Chem. 1926, 156, 237-244. [CrossRef] 
186. Jensen, K.A. Dipolmessungen an isomeren platokomplexen. Z. Anorg. Allg. Chem. 1935, 225, 97-141. [CrossRef]

187. Tsuchida, R. Absorption spectra of coordination compounds. I. Nippon Kagaku Kaishi (1921-1947) 1938, 59, 586-596. [CrossRef]

188. Tsuchida, R. Absorption spectra of coordination compounds. I. Bull. Chem. Soc. Jpn. 1938, 13, 388-400. [CrossRef]

189. Tsuchida, R. Absorption spectra of coordination compounds. II. Nippon Kagaku Kaishi (1921-1947) 1938, 59, 731-743. [CrossRef]

190. Tsuchida, R. Absorption spectra of coordination compounds. II. Bull. Chem. Soc. Jpn. 1938, 13, 436-450. [CrossRef]

191. Tumaki, T. Coordinate valency rings. V. Spectrochemical researches on the inner complex metallic salts of salicylaldehyde-ethylenediimine and related compounds. Bull. Chem. Soc. Jpn. 1938, 13, 583-591.

192. Tutida, R.; Kobayasi, M.; Kuroya, H. An extended coordination theory of valency. IV. Configuration of compounds of transition elements. Rev. Phys. Chem. Jpn. 1939, 13, 151-165. Available online: http://hdl.handle.net/2433/46556 (accessed on 4 August 2019).

193. Ewens, R.V.G.; Bassett, H. Inorganic chemical nomenclature. Chem. Ind. 1949, 131-139.

194. IUPAC; Commission de Nomenclature de Chimie Inorganique. Tentative Rules for Inorganic Nomenclature; Comptes Rendus de la Dix-Septième Conférence: Stockholm, 1953; pp. 98-119.

195. Buchner, E.H. Chem. Weekblad. 1955, 51, 295-310.

196. IUPAC. Nomenclature of Inorganic Chemistry, 1957 Report of CNIC; Butterworths Scientific Publications: London, UK, 1959.

197. Martell, A.E.; Calvin, M. Chemistry of the Metal Chelate Compounds; Prentice-Hall Inc.: New York, NY, USA, 1952.

198. Morgan, G.T.; Drew, H.D.K. Researches on residual affinity and co-ordination. Part II. Acetylacetones of selenium and tellurium. J. Chem. Soc. Trans. 1920, 117, 1456-1465. [CrossRef]

199. Lowry, T.M. Stability of co-ordination compounds. J. Soc. Chem. Ind. Lond. Rev. Sect. 1923, 42, 711-715. Available online: https://archive.org/details/ost-chemistry-chemistryindustr01soci/page/n735 (accessed on 12 August 2019). [CrossRef]

200. Smith, J.D.M. Chelate co-ordination. J. Soc. Chem. Ind. Lond. Rev. Sect. 1923, 42, 847-850. Available online: https://archive.org/details/ost-chemistry-chemistryindustr01soci/page/n871 (accessed on 12 August 2019). [CrossRef]

201. Lowry, T.M. Co-ordination and the electron. J. Soc. Chem. Ind. Lond. Rev. Sect. 1923, 42, 1004-1007. Available online: https://archive.org/details/ost-chemistry-chemistryindustr01soci/page/n1029 (accessed on 12 August 2019). [CrossRef]

202. McKenney, R.E.B. Mono- and di-basic phosphates. Science 1910, 32, 836-837. [CrossRef]

203. Ransom, J.H. Inorganic nomenclature. Science 1911, 33, 63-64. [CrossRef]

204. International Association of Chemical Societies. Nature 1912, 89, 245-246. [CrossRef]

205. K., C.G. International Association of Chemical Societies. J. Chem. Soc. 1912, 86-88.

206. Van Tiggelen, B.; Fauque, D. The Formation of the International Association of Chemical Societies. Chem. Int. 2012, 34, 8-12. [CrossRef]

207. Fennell, R.W. History of IUPAC 1919-1987; Blackwell Science: Oxford, UK, 1994.

208. Marshall, A.G. The Interallied Conference of Scientific Academies, in London. Publ. Astron. Soc. Pac. 1918, 30, 331-335. Available online: https://iopscience.iop.org/article/10.1086/122768/pdf (accessed on 4 August 2019). [CrossRef]

209. Walker, J. Presidential address delivered at the annual general meeting, March 22nd, 1923. Symbols and formulae. J. Chem. Soc. Trans. 1923, 123, 939-946. [CrossRef]

210. Chemical nomenclature. Science 1923, 57, 474. [CrossRef]

211. Comptes Rendus de la Deuxieme Conference Internationale de la Chimie. Brussels, Belgium, 1921.

212. Revision of inorganic nomenclature. Analyst 1926, 51, 192-195. [CrossRef]

213. Delépine, M. Réforme de la nomenclature chimique. Bull. Soc. Encour. Ind. Natl. 1929, 775-811. Available online: http://cnum.cnam.fr/CGI/fpage.cgi?BSPI.143/774/100/906/20/860 (accessed on 5 August 2019).

214. Meyer, R.J.; Rosenheim, A. Die Vorschläge der deutschen Nomenklaturkommission für anorganische Chemie. Z. Angew. Chem. 1925, 38, 713-715. [CrossRef] 
215. Meyer, R.J. Zur Nomenklatur der anorganischen Chemie. Z. Angew. Chem. 1929, 42, 1059-1062. [CrossRef]

216. Meyer, R.J. Rapport sur la nomenclature des combinations inorganiques. Helv. Chim. Acta 1937, 20, 159-175. [CrossRef]

217. Meyer, R.J. Chem. Weekblad. 1936, 33, 722-729.

218. Leigh, G.J. A History of CNIC. Chem. Int. 2019, 41, 39-43. [CrossRef]

219. Jorissen, W.P.; Bassett, H.; Damiens, A.; Fichter, F.; Remy, H. International Union of Chemistry. Rules for Naming Inorganic Compounds. Analyst 1940, 65, 509-511.

220. Jorissen, W.P.; Bassett, H.; Damiens, A.; Fichter, F.; Remy, H. Internationale Union für Chemie, Kommission für die Reform der Nomenklatur der anorganischen Chemie: Richtsätze für die Benennung anorganischer Verbindungen. Ber. Dtsch. Chem. Ges. A 1940, 73A, 53-70. [CrossRef]

221. Jorissen, W.P.; Bassett, H.; Damiens, A.; Fichter, F.; Remy, H. Internationale Chemische Union. Kommission für die Reform der Nomenklatur der anorganischen Chemie: Richtsätze für die Benennung anorganischer Verbindungen. Helv. Chim. Acta 1940, 23, 997-1011.

222. Jorissen, W.P.; Bassett, H.; Damiens, A.; Fichter, F.; Remy, H. Union Internationale de Chimie. Regles relatives a la nomenclature des composes mineraux. Rapport de la commission de reforme de la nomenclature de chimie inorganique 1940. Helv. Chim. Acta 1940, 23, 1012-1024.

223. Jorissen, W.P.; Bassett, H.; Damiens, A.; Fichter, F.; Remy, H. Report of the Committee for the Reform of Inorganic Chemical Nomenclature, 1940. J. Chem. Soc. 1940, 1404-1415. [CrossRef]

224. Jorissen, W.P.; Bassett, H.; Damiens, A.; Fichter, F.; Remy, H. Rules for Naming Inorganic Compounds* Report of the Committee of the International Union of Chemistry for the Reform of Inorganic Chemical Nomenclature, 1940. J. Am. Chem. Soc. 1941, 63, 889-897. [CrossRef]

225. Scott, J.D. The need for reform in inorganic chemical nomenclature. Chem. Rev. 1943, 32, 73-97. [CrossRef]

226. Chemical Nomenclature; ACS Series No 8. American Chemical Society: Washington, DC, USA, 1953.

227. Bassett, H. Some General Principles of Inorganic Chemical Nomenclature. ACS Ser. 1953, 8, 5-8.

228. Fernelius, W.C. Nomenclature of Coordination Compounds and Its Relation to General Inorganic Nomenclature. ACS Ser. 1953, 8, 9-37.

229. In Proceedings of the IUPAC Comptes Rendus of the 17th Conference; 1953; pp. 98-119.

230. IUPAC. Nomenclature of Inorganic Chemistry. 1957 Rules, 2nd ed.; Butterworths: London, UK, 1959.

231. IUPAC. 1957 Report of the Commission on the Nomenclature of Inorganic Chemistry. Nomenclature of Inorganic Chemistry Definitive Rules for Nomenclature of Inorganic Chemistry. J. Am. Chem. Soc. 1960, 82, 5523-5544.

232. Cahn, R.S. An Introduction to Chemical Nomenclature; Butterworths: London, UK, 1964.

233. IUPAC. Nomenclature of Inorganic Chemistry, 2nd ed.; Butterworths: London, UK, 1971.

234. Kelly, D.P. Sulfur and its Doppelgänger. Arch. Microbiol. 1995, 163, 157-158. [CrossRef]

235. So long sulphur. Nat. Chem. 2009, 1, 333. [CrossRef] [PubMed]

236. Cohn, R.S. An Introduction to Chemical Nomenclature, 4th ed.; Butterworths: London, UK, 1974.

237. Leigh, G.J. (Ed.) Nomenclature of Inorganic Chemistry. Recommendations Rules 1990; Blackwell: Oxford, UK, 1990.

238. McCleverty, J.A.; Connelly, N.G. (Eds.) Nomenclature of Inorganic Chemistry II. Recommendations 2000; Royal Society of Chemistry: Cambridge, UK, 2001.

239. Hartshorn, R.M.; Hellwich, K.-H.; Yerin, A.; Damhus, T.; Hutton, A.T. Brief guide to the nomenclature of inorganic chemistry. Pure Appl. Chem. 2015, 87, 1039-1049. [CrossRef]

240. Brief Guide to the Nomenclature of Inorganic Chemistry. Available online: https://iupac.org/cms/wp-content /uploads/2018/05/Inorganic-Brief-Guide-V1-3.pdf (accessed on 25 July 2019).

241. Housecroft, C.E.; Sharpe, A.G. Inorganic Chemistry, 5th ed.; Pearson: Harlow, UK, 2018.

242. Brief Guide to the Nomenclature of Inorganic Chemistry. Available online: https://www.qmul.ac.uk/sbcs/iu pac/BriefGuide/inorganic.html (accessed on 5 August 2019).

243. Seidel, S.; Seppelt, K. Xenon as a Complex Ligand: The Tetra Xenono Gold(II) Cation in $\mathrm{AuXe} 4^{2+}\left(\mathrm{Sb}_{2} \mathrm{~F}_{11}{ }^{-}\right)_{2}$. Science 2000, 290, 117-118. [CrossRef] [PubMed] 
244. REACH Legislation. Available online: https://echa.europa.eu/regulations/reach/legislation (accessed on 25 July 2019).

245. Streng, A.G.; Grosse, A.V. Acid of Krypton and Its Barium Salt. Science 1964, 143, 242-243. [CrossRef]

(C) 2019 by the author. Licensee MDPI, Basel, Switzerland. This article is an open access article distributed under the terms and conditions of the Creative Commons Attribution (CC BY) license (http://creativecommons.org/licenses/by/4.0/). 